\title{
Barriers and Drivers for Circular Economy 2.0 on the Firm Level: Russian Case
}

\author{
Svetlana Ratner ${ }^{1,2}$, Konstantin Gomonov ${ }^{1, * \mathbb{D}}$, Inna Lazanyuk ${ }^{1}$ (D) and Svetlana Revinova ${ }^{1}$ (D) \\ 1 Department of Economic and Mathematical Modelling, Peoples' Friendship University of Russia \\ (RUDN University), 6 Miklukho-Maklaya Street, Moscow 117198, Russia; ratner-sv@rudn.ru (S.R.); \\ lazanyuk-iv@rudn.ru (I.L.); revinova-syu@rudn.ru (S.R.) \\ 2 Economic Dynamics and Innovation Management Laboratory, V.A. Trapeznikov Institute of Control Sciences, \\ Russian Academy of Sciences, 65 Profsoyuznaya Street, Moscow 117997, Russia \\ * Correspondence: gomonov-kg@rudn.ru; Tel.: +7-495-433-40-65
}

Citation: Ratner, S.; Gomonov, K.; Lazanyuk, I.; Revinova, S. Barriers and Drivers for Circular Economy 2.0 on the Firm Level: Russian Case. Sustainability 2021, 13, 11080. https://doi.org/10.3390/ su131911080

Academic Editors: Victor Scholten, Hanieh Khodaei, Fatima Delgado and Yvette Baggen

Received: 31 July 2021

Accepted: 2 October 2021

Published: 7 October 2021

Publisher's Note: MDPI stays neutral with regard to jurisdictional claims in published maps and institutional affiliations.

Copyright: (c) 2021 by the authors. Licensee MDPI, Basel, Switzerland. This article is an open access article distributed under the terms and conditions of the Creative Commons Attribution (CC BY) license (https:/ / creativecommons.org/licenses/by/ $4.0 /)$.
Abstract: Historically, the development of the circular economy (CE) proceeds from the CE 1.0 stage, characterized by attention to waste management and recycling, to the CE 2.0 stage with an emphasis on resource efficiency and eco-efficiency, to the current CE 3.0 stage, in which the key factor to a company's success is the business model. However, not all countries of the world simultaneously began transforming the national economy from a linear model to a circular one; many are still at the CE 1.0 and CE 2.0 stages, and do not have a developed system of institutions supporting the circular economy. In Russia, the concept of a circular economy has not yet received recognition in society and government; the stage of its development can be defined as CE 2.0. This study compares the barriers and drivers of CE development in the EU countries, a group of countries with a welldeveloped institutional support system, and in Russia, a country that does not have such a system. The study reveals that the most significant difference between countries with mature systems of institutional support and Russia lies in the regulatory sphere and in information and awareness about new available technologies and ways to increase resource efficiency, commercial attractiveness, and organizational feasibility. Changes in the first sphere are impossible without the participation of the national authorities; however, changes in the information sphere are feasible even without the government's support. The actors in such changes can be international companies with access to resource-efficient new technologies and processes for organizing business.

Keywords: circular economy; resource efficiency; survey; cluster analysis; institutional system

\section{Introduction}

The circular economy (CE) is now gaining increasing support in the business community and at the level of national authorities around the world as a model of economic growth that allows society to overcome resource constraints and stop the growth of the negative impact of economic activities on the environment [1-3].

Business plays a critical role in the development of a circular economy. Without the transition of enterprises and organizations to circular models, conscious consumer behavior alone cannot change the economic model. Changing consumer behavior patterns is a matter for each individual, but only manufacturers can become real leaders in this process $[4,5]$. However, the implementation of even proven circular business models is not an easy task for enterprises [6-11]. All modern business tools were formed under the influence of a linear model of the economy and boil down to achieving two main goals reducing production costs and increasing sales. These tools are not designed for a circular economy [4,12]. Therefore, institutional support is urgently needed to launch changes in businesses and society $[13,14]$. In this context the governments of developed countries that have adopted CE strategies at the national level are introducing various measures to support enterprises striving to implement circular models and, conversely, to discourage 
inefficient use of resources, increased waste generation and other negative impacts of enterprises on the environment [15-21]. Examples of incentive measures include grants and subsidies to develop innovations in the circular economy [22,23], while an example of discouraging measures can be the introduction of a carbon tax or the principle of extended producer responsibility for the collection and disposal of used products $[24,25]$.

Currently, the barriers faced by enterprises in implementing the principles of a circular economy and the factors stimulating the transition to circular models are well understood in the literature. However, regarding country context, the largest amount of studies related to the $\mathrm{CE}$ focuses on Chinese companies, while the second highest amount of academic papers concerned the United Kingdom and EU [26-34]. All these countries have a mature system of institutions that support the development of a circular economy.

In Russia, the concept of a circular economy has not yet received recognition in society and national authorities. Some of its elements are being implemented within the framework of the national project "Ecology" [35,36], or are reflected in regulatory legal acts [37-39], in particular, in the amendments to Federal Law 89-FZ "On Production and Consumption Waste", the purpose of which is to introduce the principle of extended producer responsibility [40]. However, even the terminology in circular economics does not yet have a standardized translation into Russian. More often, the scientific and analytical literature uses the term "resource efficiency", which generally reflects the principles of circularity, at least in the production sphere [41]. There is no established system of institutions to support the development of the CE in Russia.

Therefore, the main research question that we set ourselves in this work is to determine whether the circular economy's barriers and drivers differ between Russia and countries with a developed institutional support system. If such differences exist, then what is their focus and magnitude? The answer to these questions has many important practical applications, from the most obvious, such as what changes must take place for enterprises to move better and faster to circular business models, to more complex ones, such as how international institutions and business can influence the development of a circular economy in countries where the authorities are not yet involved.

The paper is organized as follows. Section 2 presents the results of literature review and systemizes the theoretical framework of the study. Section 3 describes the methodology of empirical research for comparative study of the barriers and drivers of resource efficiency as a key area of CE principles implementation at the firm level, and the methodology of clusterization of countries in the research sample for identifying the most similar countries in different areas dealing with resource efficiency. Section 4 presents and discusses the results of cross-countries empirical research and the results of cluster analysis. Finally, conclusions and policy applications are presented in Section 5 .

\section{Literature Review}

Throughout the last few years the number of publications on circular business has grown exponentially. Several systematic reviews have been undertaken just recently, which greatly simplifies our task in analyzing research background.

In one of the most massive reviews, Schoggl and co-authors [42] analyze 3822 journal papers on circular economy, published between 2000 and 2019. They report that top five discussed topics in CE research are (1) conceptualization of CE and its correlation with sustainable development; (2) resource efficiency (energy and waste management, recycling, environmental management); (3) industrial symbiosis (mostly in the Chinese context); (4) life-cycle of materials; (5) production and products. They also note that most papers include the social dimension in the focus of research to a certain extent, yet the new findings remain environmental or economic. From a historical perspective, the focus of research on the circular economy moves from technological innovation (including the questions on regulatory framework for stimulating research and development and investment in $\mathrm{CE}$ ) to innovations in business models or service innovations. 
In the most recent paper from the same academic team [43] the authors investigated 131 case studies from the Circular Economy Industry Platform (CEIP) database to identify barriers that companies face in CE projects. They found that the main barriers are regulatory (lack of definitions/standards, lack of government enforcement and cooperation, and lack of harmonization in European legislation). Other barriers are high costs, lack of proven technologies, lack of awareness, lack of demand, and difficulties with logistics. The authors also questioned how different enablers and principles influence the CE implementation in companies. They conclude that recycling and recovery are the most popular CE principles despite their weak impact on circularity and sustainability. In contrast, implementing "stronger" circular principles such as Reduce, Reuse, and Redesign is still rare.

Reike and co-authors also use a historical perspective in their literature review [41] and suggest distinguishing three phases in evolution of the CE concept, from CE 1.0 to CE 3.0. They describe CE 1.0 (1970-1990) as mostly waste management and recycling, while CE 2.0 (1990-2010) primarily deals with eco-efficiency and resource efficiency. The authors refer to the current stage of circular concept evolution as CE 3.0 and report that modern literature focuses on the "resource trap" and how to move from efficiency in consumption of natural resources to sufficiency, i.e., how to change consumption patterns. They also highlight factors of CE 3.0 development that are associated with business models, organizational culture, and stakeholder involvement. While the suggested periodization seems reasonable, we can say that CE is still referred as resource efficiency in many papers on both developed [9,44-47] and emerging economies [48-51].

In a systematic literature review conducted by Geissdoerfer and co-authors [52], the focus of research lies on circular business models. They trace the history of the circular business model concept and connect it with circular business model innovations. The authors list four general strategies for circular business (cycling, extending, intensifying, dematerializing) and describe the four different types of circular business model innovation (circular start-ups, circular business model diversification, circular business model transformation, and circular business model acquisition). They highlight that businesses should consider CE as a new way of making a profit, not just a tool to increase resource efficiency and become more stable in terms of raw materials price volatility.

This conclusion contrasts with Loon et al. [53], who argue that not all circular business models have a positive environmental impact. In their recent systematic literature review of the studies that discuss the environmental impact of circular products and/or circular business models, they have found much evidence that extending the life cycle of products does not reduce environmental burden (energy efficiency or product deterioration over time, rebound effects etc.). Although the circular economy is not limited only to resource efficiency, all circular business models must be tested in terms of resource efficiency and environmental effects.

In their systematic review of recent literature on the topic of circular business, Barros et al. [54] identify key impacts of circular economy practices within different business areas (strategic planning, cost management, supply chain management, quality management, environmental management, process management, logistics and reverse logistics, service management, and research and development). This study reports that circular practices contribute to greater resource efficiency, help to gain strategic advantages by turning products which are at the end of one of their life cycles into resources, and to become less vulnerable to virgin material price shocks. At the same time, changing from a linear to a circular model may require much investment, knowledge, managerial effort, change in organizational culture, and networking with partners along the supply chain.

Centobelli et al. [55] in their systematic literature review on the circular business model design have demonstrated that companies have to implement some managerial practices that are specific to each dimension of the business model (value creation, value transfer, and value capture). They also emphasize the role of policymakers and international institutions in boosting radical change in the global economic model, and admit that 
algorithms on creating a favorable environment and a responsible political agenda are still under-investigated.

Sarja and colleagues [26] also conducted a systematic literature review focusing on the obstacles, catalysts, and ambivalences for $\mathrm{CE}$ transition. The most surprising aspect of their review is the finding that legislation is an ambivalent factor, which in certain circumstances can be a barrier for CE implementation and in other circumstances can stimulate it. Governments try to create favorable conditions for transition to the circular models through legislation, but legislation is often not updated as fast as business cases and new technologies develop. In this situation, newly commercial options based on circular solutions may face some restrictions. Maitre-Ekern, in his recent paper [4], investigates this phenomenon in detail using the example of Extended Producer Responsibility (EPR) legislation and argues that in actual European practice this CE policy fails to promote waste prevention.

Werning and Spinler, in their study [56], have found 29 barriers that hinder companies from undertaking business model transformation to a more circular one. They identify 27 firm-level barriers through extensive literature review and add two more barriers to this list by conducting a case study of the electronics manufacturing industry. The authors prioritize barriers based on their impact on the value chain and on how hard they are to overcome. They argue that the barriers with the highest priority are the following: "End to end visibility", "Fashion vulnerability", "Optimal production setup", "Performance based sales", "Feedstock volatility", "Willingness to take on long-term strategy", "Correct forecast of needed spare parts", and "Potential cannibalization of new sales".

Morseletto [57] postulates that targets play a fundamental role in stimulating transitions from a linear to a circular economy and examines the targets of circular economy mentioned in 59 recent academic papers and 13 policy documents and analytical reports. He concludes that although the circular economy has multiple goals, the main priorities are resource efficiency and extending product life. In addition to extensive literary reviews, it is worth highlighting several works in which primary data were collected through a case study, report analysis, or survey. Thus, Urbinati and co-authors [58], in their multiple case study analysis of European manufacturing industry, pay special attention to the question of how environmental regulation (such as requirements to improve energy efficiency or reduce greenhouse gas emissions) influenced the design of a circular business model and the implementation of the circular managerial practices in each of the sampled cases. Based on the information collected from primary sources by interviewing first-line managers and senior researchers, the authors conclude that environmental regulation (more generally, external environmental conditions) plays a key role in shaping the circular business model and in the adoption of certain managerial practices.

Salvador and co-authors [59], using expert interviews and the Fuzzy Logic approach, demonstrated that developing strategic partnerships, engaging stakeholders along the value chain, and extensive implementation of digital technologies are the most efficient strategies to improve circularity. Kristoffersen and colleagues in their recent study [60] interviewed 125 European firms. They concluded that mature digital companies with a strong business analytics capability as a part of their information system have better chances to excel in the circular economy. In their previous paper [61] authors refer to digitalization in CE as the Smart CE concept.

In the paper of Holzer et al. [47] on the topic of corporate circular practices, empirical data was gathered by a cross-sectional survey of 183 small and medium Austrian enterprises. The paper's main finding is that Austrian entrepreneurs consider resource efficiency as a key opportunity for their business and underestimate cooperation with stakeholders in the transition to a circular model. The last finding is quite surprising considering the extended body of literature from European countries highlighting the importance of networking and cooperation with partners in the practical implementation of $\mathrm{CE}$ principles. For example, Alonso-Almeida with co-authors in their recent paper [62] clearly showed that transitioning from a linear model of the economy to a circular one is a divergent change 
that needs an institutional entrepreneur to push it forward. Using structural modeling, they proved that cross-sectorial collaborations with public sector support are one of the most effective ways to change current business models to circular ones.

The recent study of Fortunati et al. [63], based on an analysis of reports of the biggest companies in the cosmetics industry, proves that the CE concept is mostly understood in terms of resource efficiency. Another recent paper of Fortunati with co-authors [64] focuses on the understanding of CE strategies in the Italian food industry and concludes that companies in the food sector are intent on practicing CE; however, it is sometimes not specifically indicated in their policies.

Summarizing the literature analysis, we can draw several conclusions: (1) even though the concept of a circular economy goes far beyond simple resource efficiency, at the level of an individual enterprise, resource efficiency is still the most important priority in the transition to a circular model, even in countries where the $\mathrm{CE}$ concept has been promoted at the institutional level for a long time; (2) the barriers and drivers of the practical implementation of the principles of a circular economy have been studied quite well from a theoretical point of view, but there is little empirical data on what enterprises themselves (especially small and medium-sized ones) consider barriers and drivers, even for countries with a developed system of institutional support for CE. We have not found such data for the countries with developing economies and those without institutional support for the CE.

Taking into account the identified gaps in the literature, the purpose of our study was to conduct an empirical study of the barriers and drivers of the practical implementation of CE principles in Russia, as a country that has not yet formed a system of institutional support for the transition from a linear model of the economy to a circular one. The first research question of this work is how much the barriers and drivers coincide (or how different they are) in a country that does not have a developed system of institutional support for the CE (i.e., Russia) as opposed to countries with an existing system of institutional support (i.e., the European Union). The second question is, to which group of European countries and in which area of institutional support Russia is closest. The answer to the second question is of practical importance since the examples of such countries can be used to build institutions for CE development in Russia.

\section{Methods and Data}

To compare the CE barriers and drivers in the EU (as a group of countries with a well-developed institutional support system) with those in Russia (as a country that does not have such a system), we interviewed business representatives using a questionnaire compiled within the framework of the project Flash Eurobarometer 456 "SMEs, resource efficiency and green markets" [65]. This project studied 28 Member States of the EU as well as Albania, the Former Yugoslav Republic of Macedonia, Montenegro, Serbia, Turkey, Iceland, Moldova, Norway and US. The questions in this questionnaire were designed in such a way as to obtain data about current planned resource efficiency actions of companies, the reasons for taking them, barriers when implementing resource efficiency actions, and the role and impact of policy in supporting resource efficiency initiatives. The Directorate-General developed the original methodology of the survey for Communication [66]. Contrary to the methodology suggested in a recent study of García-Sánchez et al. [67], the methodology of Eurobarometer is aimed not only at identifying the actions of companies in their introduction of the CE principles of a circular economy but, to a greater extent, at identifying what kind of support the company needs and whether it receives such support.

In a survey of European companies, there was also a block of questions about green markets. In the study for Russia, this block of questions was skipped, firstly, because green products are not always circular [68], and secondly in order not to confuse respondents, who do not always have a correct understanding of what "green products" are [69]. The list of questions is presented in Appendix A. 
The survey of Russian enterprises was carried out in April-June 2020. Since Russian companies are reluctant to disclose information about themselves, we used the authors contacts with entrepreneurs during the survey. In a personal conversation, the authors previously introduced business representatives (heads or top managers of companies) to the purpose and procedure for conducting the study and obtained their agreement to submit a questionnaire. In total, 53 companies took part in the survey with a response rate of $100 \%$. The distribution of companies by size, sector of the economy and region of operation is presented in Table 1. After coding, the respondents' responses were processed using frequency analysis.

Table 1. Distribution of companies by size, sector of the economy and region of operation.

\begin{tabular}{|c|c|c|c|}
\hline Attributes & Value & Frequency & $\%$ \\
\hline \multirow{3}{*}{ Size } & Small (<100 employers) & 34 & 64.15 \\
\hline & Medium (101-249 employers) & 12 & 22.64 \\
\hline & Big (250+ employers) & 7 & 13.21 \\
\hline \multirow{14}{*}{ Sector } & Commerce & 11 & 20.75 \\
\hline & Cafes and restaurants & 4 & 7.54 \\
\hline & Audit, consulting and education & 5 & 9.43 \\
\hline & IT & 3 & 5.66 \\
\hline & Culture & 2 & 3.77 \\
\hline & Beauty shop & 2 & 3.77 \\
\hline & Logistics & 4 & 7.54 \\
\hline & Construction & 2 & 3.77 \\
\hline & (9) Industry & 11 & 20.75 \\
\hline & (10) Agriculture & 1 & 1.89 \\
\hline & (11) Insurance and finance & 2 & 3.77 \\
\hline & (12) Publishing & 1 & 1.89 \\
\hline & (13) Recycling & 1 & 1.89 \\
\hline & $(14) \mathrm{N} / \mathrm{A}$ & 4 & 7.54 \\
\hline \multirow{9}{*}{ Region } & (1) Moscow & 27 & 50.94 \\
\hline & Moscow and Moscow region & 12 & 22.64 \\
\hline & Russia (all regions) & 7 & 13.21 \\
\hline & Russia and abroad & 1 & 1.89 \\
\hline & St. Petersburg & 1 & 1.89 \\
\hline & Republic of Mordovia & 1 & 1.89 \\
\hline & Rostov region & 2 & 3.77 \\
\hline & Ural region & 1 & 1.89 \\
\hline & Republic of North Osetiya-Alaniya & 1 & 1.89 \\
\hline
\end{tabular}

Source: authors.

As the second stage of the study, we conducted a cluster analysis of the distribution of companies' responses from each of the countries included in the two surveys, Flash Eurobarometer 456 and Russia. We used the k-means method. Unlike in the recent studies of Fura et al. [70] and Gomonov et al. [71], which were also carried out by cluster analysis, the purpose of this study was not to rank countries by the level of CE development (in general or in some particular aspects), but rather to identify the groups of countries with a similar system of institutional support. 
The percentage of respondents who chose each answer option for each of the questionnaire's eight questions was considered a separate variable. Therefore, the values of the variables did not need a preliminary standardization procedure. The analysis was carried out using Statistica 12.0 software (Russia). Distances between objects (countries) were calculated using the Euclidean metric

$$
d_{E}\left(X_{i}, X_{j}\right)=\sqrt{\sum_{k}\left(X_{i k}-X_{j k}\right)^{2}}
$$

where:

$X_{i}, X_{j}$-objects (countries), represented as a vector in $N$-dimensional space,

$\mathrm{N}$-total number of possible answers in the survey,

$X_{i k}$-share of companies in country number $i$ which choose answer number $k=\overline{1, N}$

An agglomerative clustering procedure was used; the objects were combined into clusters using Ward's method. The increment in the sum of the squares of the distances of objects to the centers of the clusters is taken as the distance between the clusters [72]. Unlike other methods of cluster analysis to estimate the distances between clusters, this method uses analysis of variance. At each step of the algorithm, two clusters are combined, leading to a minimum increase in the objective function, i.e., intragroup sum of squares. This method aims at combining closely spaced clusters and tends to create small clusters.

The number of clusters was a priori assumed to be five in order to make the clustering results easy to interpret. When all countries are divided into a larger number of clusters (for example, six, seven, eight or more), the difference between the clusters becomes less obvious, and it becomes difficult to draw any meaningful conclusions and recommendations from the results obtained. When all countries are divided into smaller clusters (four, three or two), the number of countries included in each cluster becomes too large. Countries with significantly different levels of socio-economic development, innovative development, institutional structure, etc. are thus combined into one cluster.

\section{Results and Discussion}

4.1. Comparative Analysis of the Answers of Russian Companies with Average among Companies in EU

The distribution of answers on the current actions companies are taking to be more resource efficient (Q1) is presented in Figure 1.

The first three most popular resource-saving measures in Russia are the same as in the EU. Almost half of all Russian companies say they are minimizing waste (49.1\%). The second most popular action is saving energy $(47.2 \%)$, followed by saving materials $(45.3 \%)$. Unlike in the EU, only $3.8 \%$ of Russian companies use predominantly renewable energy, and $11.3 \%$ are designing products that are easier to maintain, repair or reuse. The same share of Russian companies as in the EU (11.3\%) take no actions to improve their resource efficiency.

Then we asked companies about additional resource efficiency actions they were planning to implement in the next two years $(\mathrm{Q} 2)$. The distribution of answers is presented in Figure 2. 

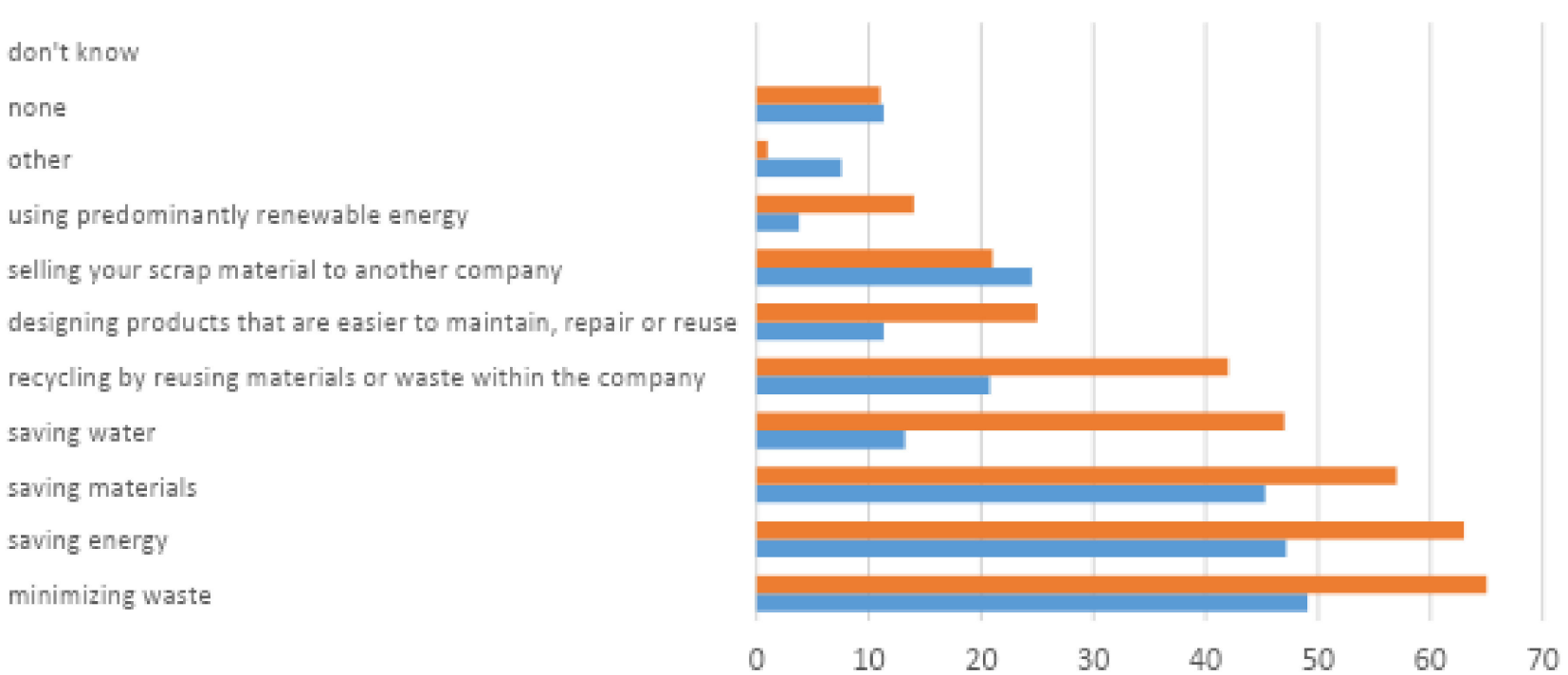

RU EU

Figure 1. What actions is your company undertaking to be more resource efficient? (multiple answers are possible). Source: authors.
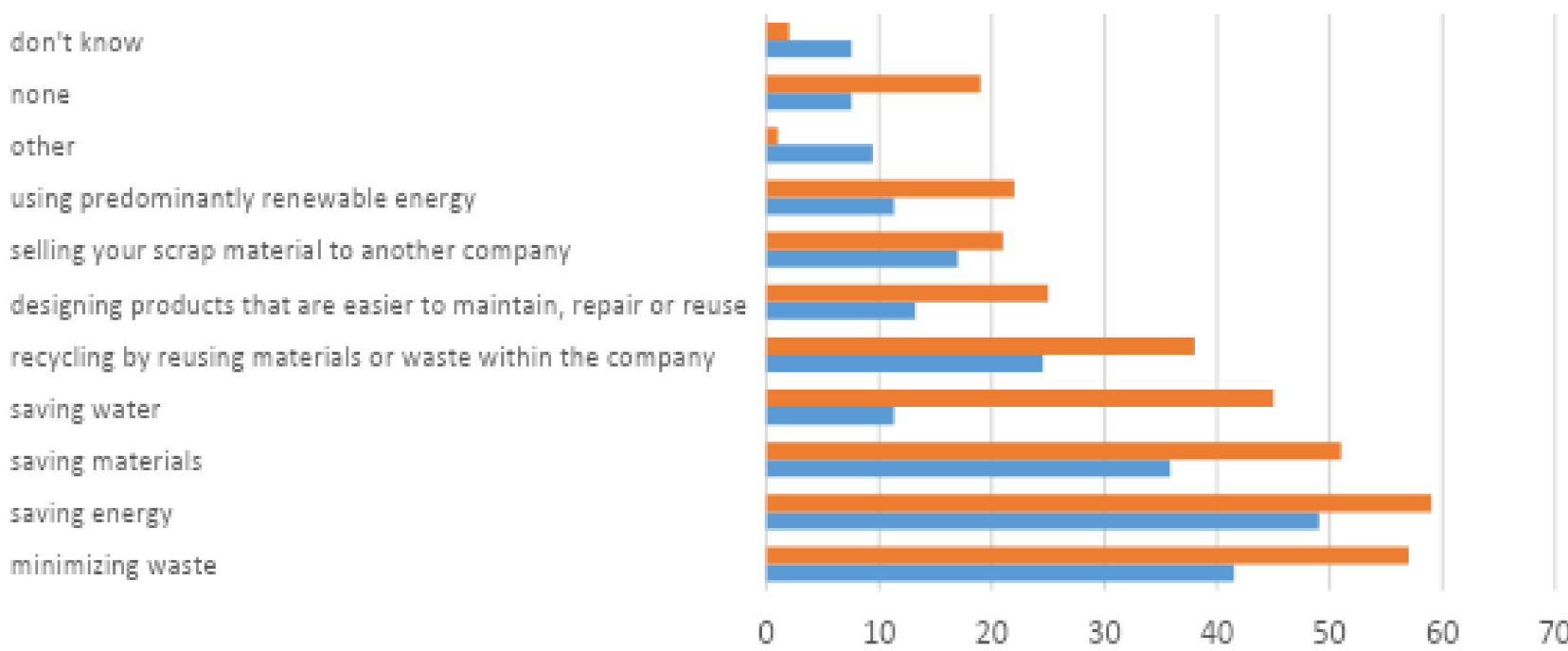

RU DEU

Figure 2. Over the next two years, what are the additional resource efficiency actions your company plans to implement? Source: authors.

The most noticeable difference in the answers to this question between Russian and European companies is in the responses to water saving and renewable energy sources. The most significant share of Russian companies will save energy (59\%), then $57 \%$ will minimize waste, and $51 \%$ will save raw materials. Note that these measures are the most popular among EU companies as well. Only $11.3 \%$ of Russian companies are going to take actions aiming to save water, versus $45 \%$ of European companies. Only $11.3 \%$ of companies 
in Russia are going to use renewable energy, compared to $22 \%$ of companies in Europe. Surprisingly, only $7.5 \%$ of Russian companies will not take any actions at all, versus $19 \%$ of such companies in the EU.

The next question was about the impact companies' resource efficiency actions have had on production costs over the past two years. The respondents could choose the answer from the following variants: (1) significantly decreased; (2) slightly decreased; (3) slightly increased; (4) significantly increased; (5) not changed; (6) I do not know (Figure 3).

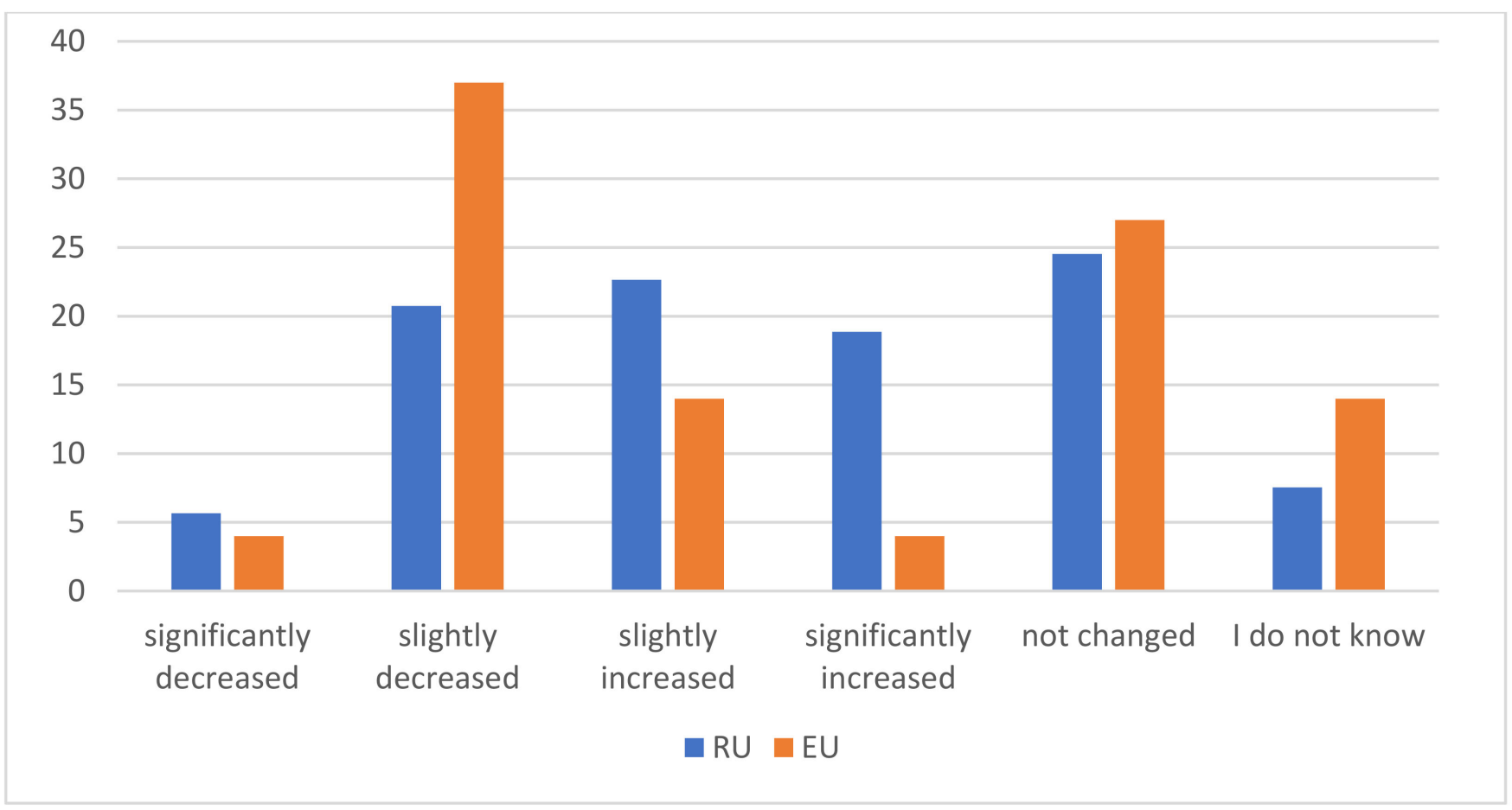

Figure 3. The impact of resource efficiency actions on production costs. Source: authors.

Compared to the answers of EU companies, more Russian enterprises report that their resource efficiency action increased the production costs; $22.6 \%$ of Russian companies state that their production costs increased slightly (versus $14 \%$ in the EU) and nearly $19 \%$ reported that their production costs increased significantly, compared to only $4 \%$ in Europe.

The levels of investment in resource efficiency actions in Russia and the EU are almost the same (Figure 4); 32\% and 30\% of surveyed companies did not invest in resource efficiency in Russia and Europe, respectively (Figure 4), while 32\% vs 25\% supported less than $1 \%$ of annual turnover. We can note that the biggest gap between Russian and European companies in the level of investment is 1-5\% of annual turnover: only $11.3 \%$ of surveyed Russian companies have this level of investment in resource efficiency, compared to $25 \%$ in the EU.

In Question 5, we asked companies about the kind of support they rely on when trying to be more resource efficient; $75.5 \%$ of companies in Russia and $60 \%$ of companies in the EU rely on their financial resources (Figure 5). The share of the companies relying on their technical expertise in the EU is a little more significant than in Russia: $58 \%$ versus $51 \%$. The share of companies relying on external support is also somewhat larger in the EU, $22 \%$ compared to only $9.5 \%$ in Russia. 


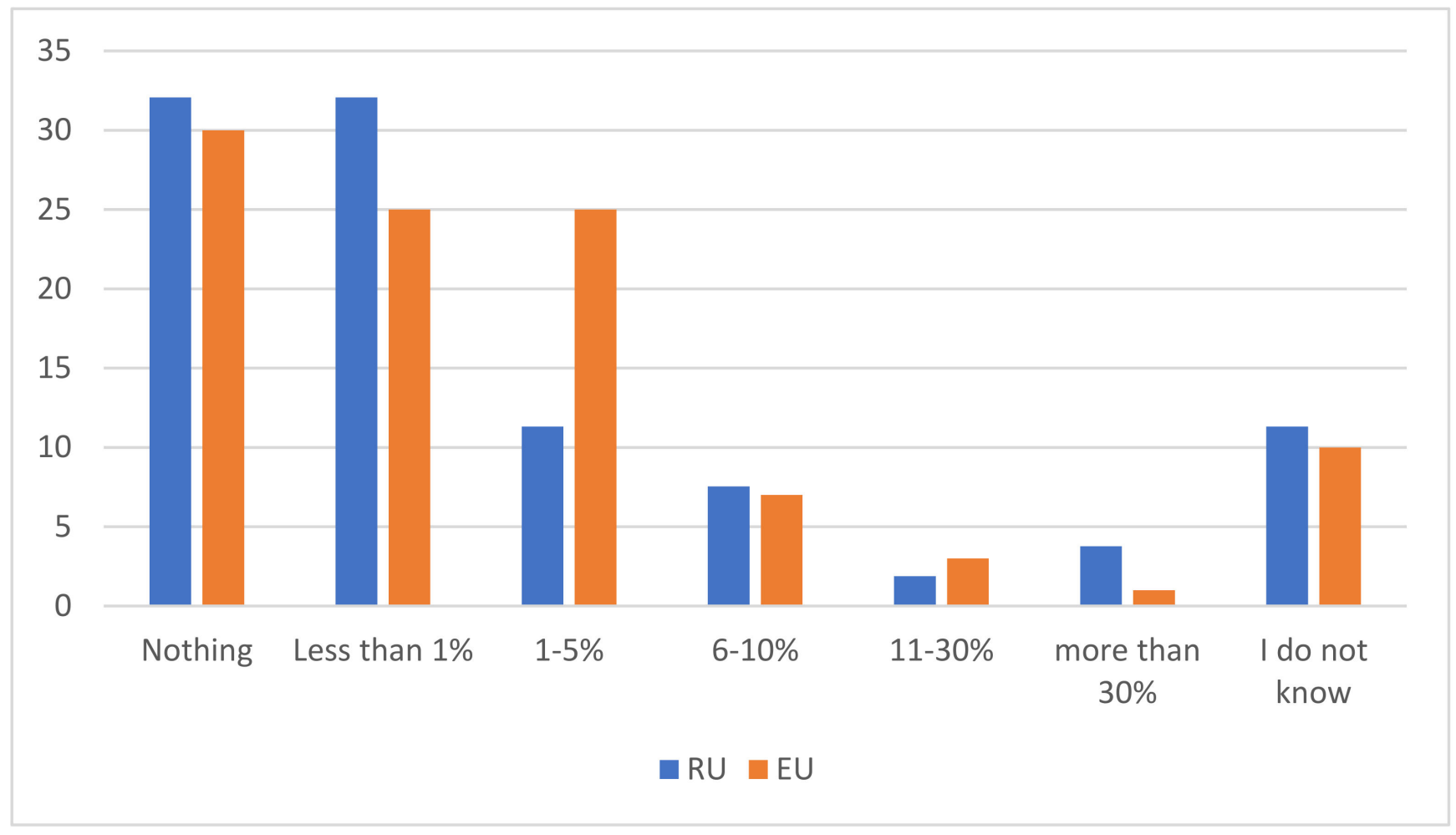

Figure 4. Levels of investment in resource efficiency actions. Source: authors.

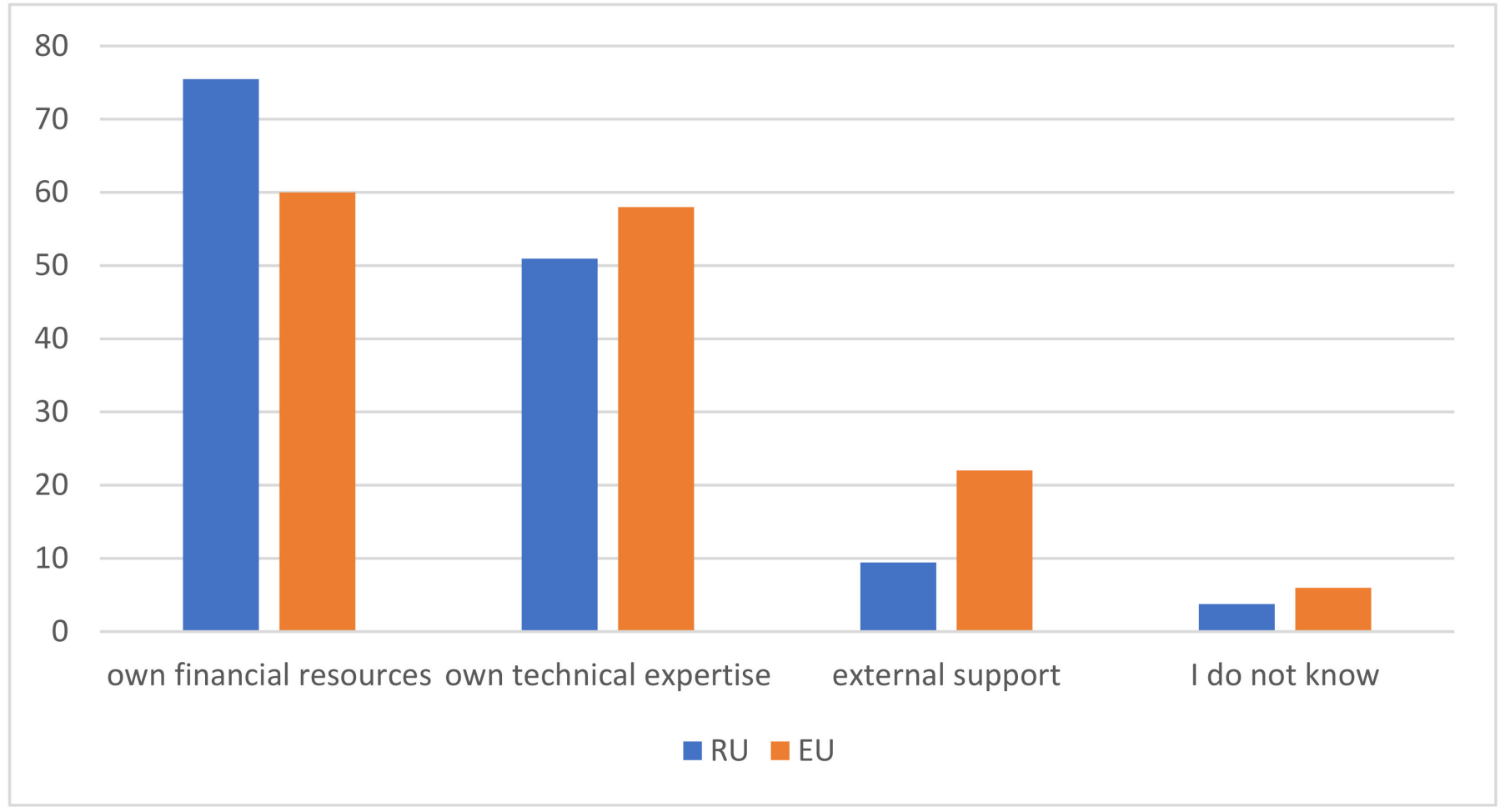

Figure 5. Types of support in resource efficiency actions. Source: authors.

Next, the companies that rely on external support were asked for more detail about the kinds of support they receive; the distribution of answers in Russia and in the EU differ significantly (Figure 6). In the EU almost half (47\%) of all companies report that they receive advice or other non-financial assistance from private consulting and audit 
companies (the most popular option). In Russia the share of such companies is only $12.5 \%$. $31 \%$ of companies in the EU take advice or other non-financial assistance from business associations, while 30\% take private funding from a bank, investment company or venture capital fund. In Russia, the shares of such companies are only $17.5 \%$ and $20 \%$, respectively.

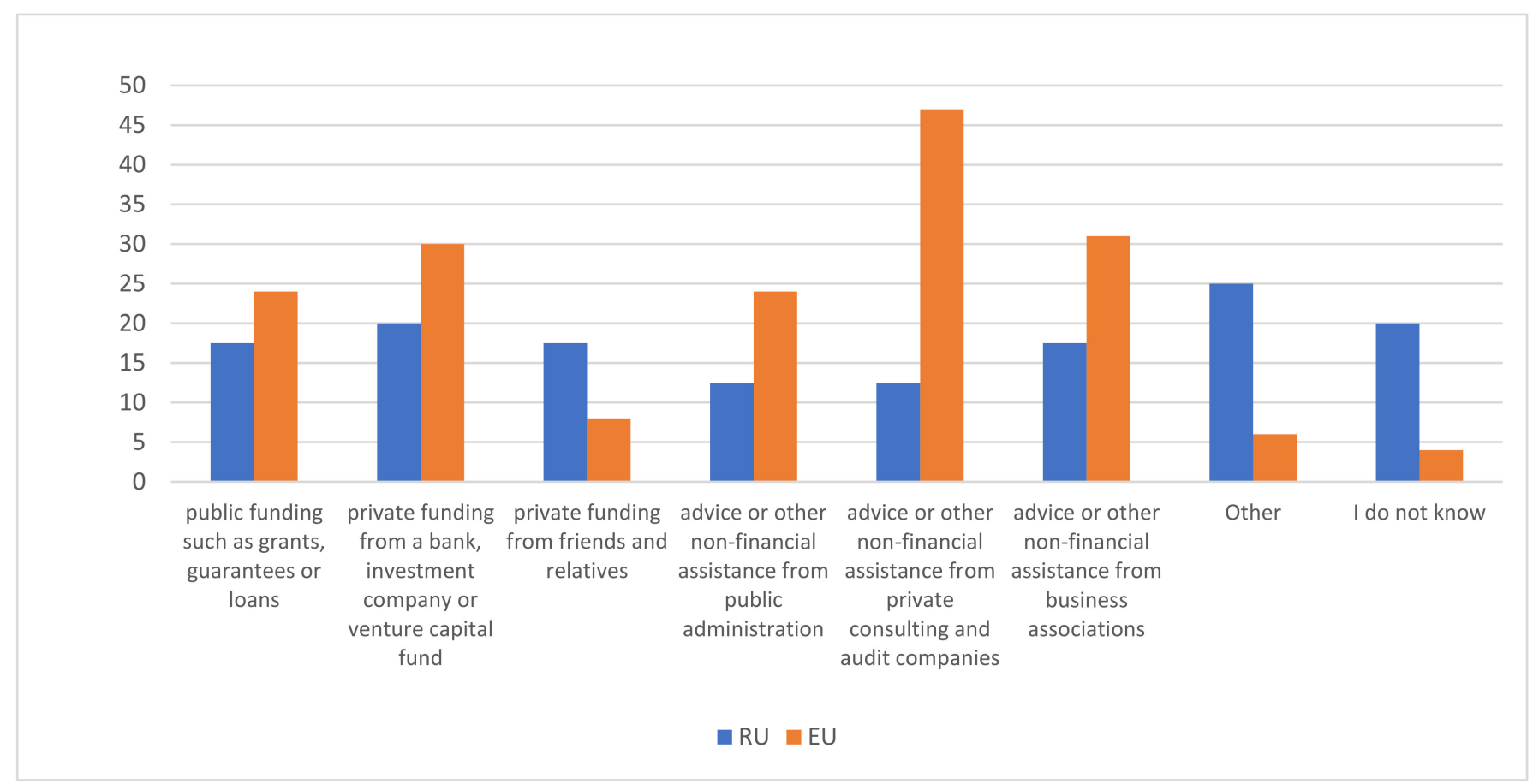

Figure 6. Types of external support used by enterprises to be more resource efficient. Source: authors.

Among the European companies, almost a quarter say that they receive public funding (grants, guarantees or loans). The same share say that they use advice or other nonfinancial assistance from public administration (Figure 6). Among Russian companies, only $17.5 \%$ receive public funding and only $12.5 \%$ use non-financial assistance from public administration. Only $8 \%$ of companies in the EU rely on private funding from friends and relatives, compared to $17.5 \%$ in Russia.

Then, asking about barriers to a higher level of resource efficiency, almost $40 \%$ of European companies answer that they had none, compared to only $2 \%$ of such companies in Russia (Figure 7), the biggest difference to this point. Otherwise all of the main problems are similar: the most frequently mentioned barrier is the complexity of administrative or legal procedures (mentioned by $37.7 \%$ of respondents in Russia versus 33\% in the EU), difficulty of adapting environmental legislation to a specific company (mentioned by $30.2 \%$ of Russian companies versus $22 \%$ in EU), technical requirements in the legislation not being up to date (mentioned by $28.3 \%$ of respondents in Russia versus $20 \%$ in EU), and the cost of environmental actions (26.4\% in Russia and $24 \%$ in EU).

The survey's final question was about measures the companies would suggest to help them become more resource efficient. The companies could choose a maximum of three options (Figure 8). Surprisingly, the two most popular answers from Russian companies were "Demonstration of new technologies or processes to improve resource efficiency" (47.1\%) and "Better cooperation between companies across sectors so that new processes to reuse waste and byproducts can be developed" (39.6\%). In Europe, these measures were chosen only by $22 \%$ and $20 \%$ of surveyed companies, respectively (Figure 8 ). The answer "Grants or subsidies" was popular both in Russia (chosen by $37.7 \%$ of companies) and in the EU (36\%). However, in the EU it was the leader among all other desirable measures, while in Russia it was only the third most likely choice. Another interesting distinction is 
that $20 \%$ of European companies say that none of the suggested measures will help them to improve resource efficiency, whereas no Russian company chose this answer.

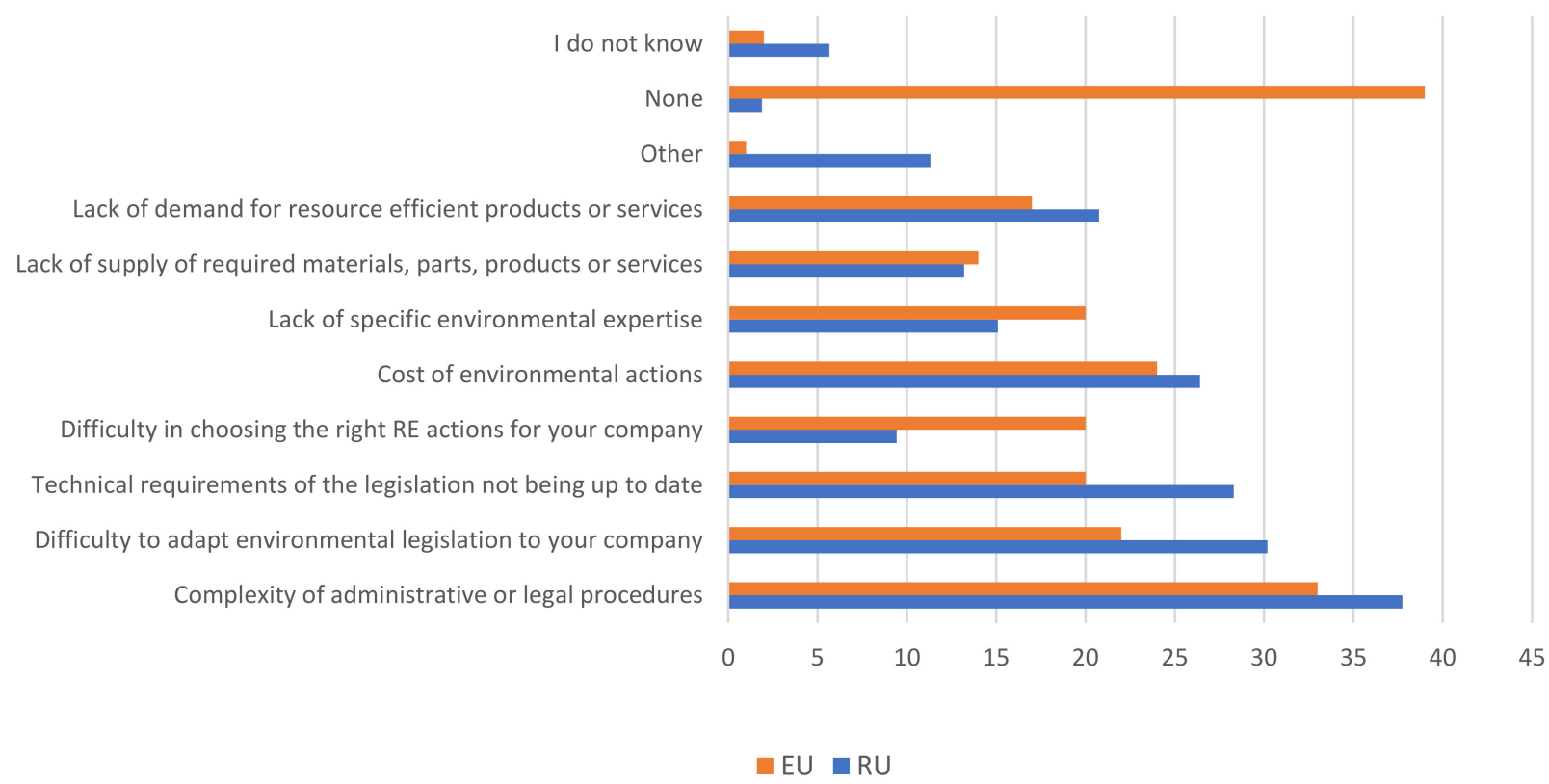

Figure 7. Barriers encountered when becoming more resource efficient. Source: authors.

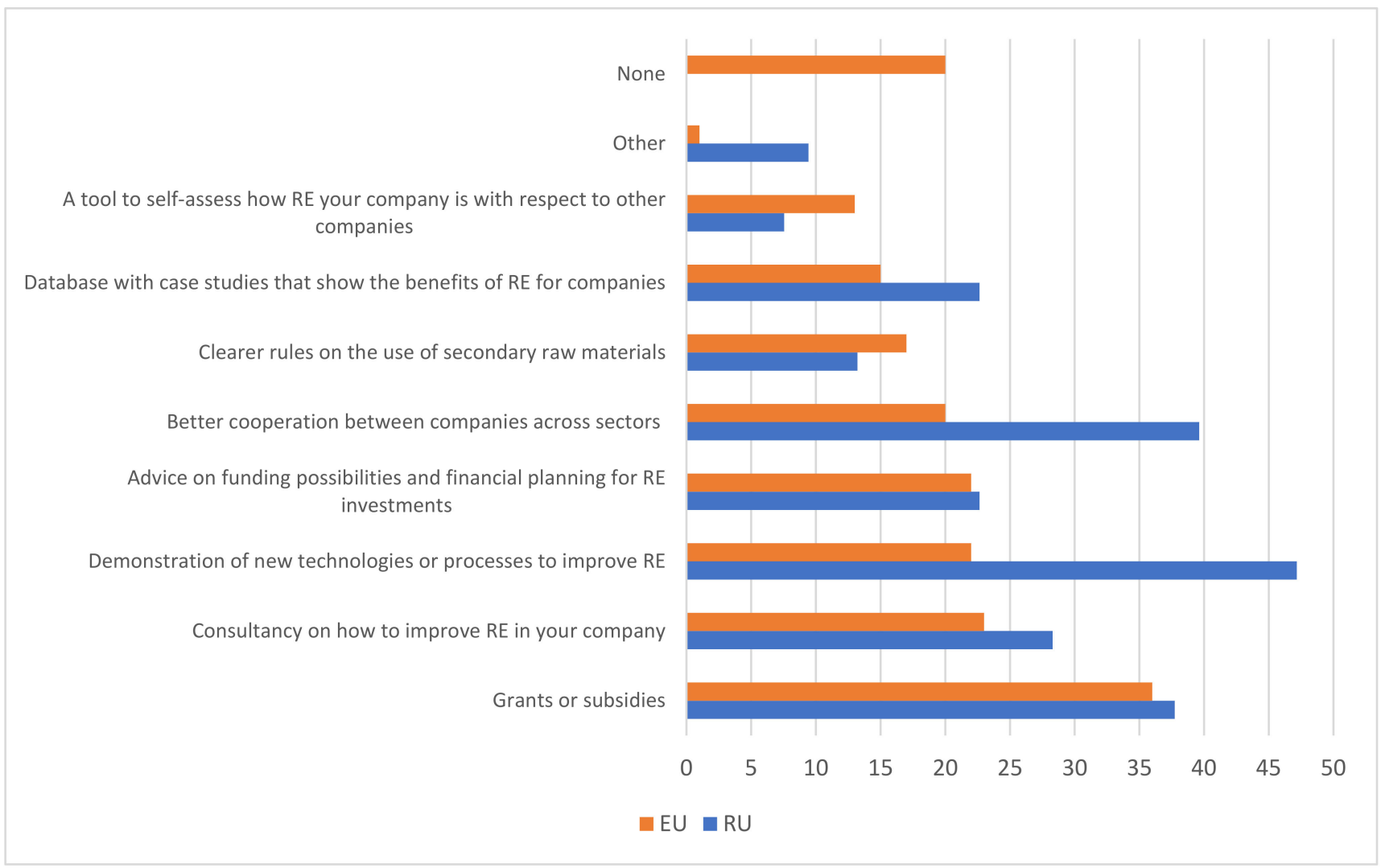

Figure 8. Desirable measures supporting resource efficiency. Source: authors.

Thus, the results of our survey confirm that Russian companies have barriers to the development of the circular economy 2.0, which were previously revealed in Schoggl et al. [43]. These include a lack of government enforcement and cooperation, a lack of proven technolo- 
gies, a lack of awareness, and the high cost of resource efficiency innovations. However, the prioritization of barriers differs from the prioritization in EU companies. Russian companies are more sensitive to imperfect government regulation and the lack of cooperation with cross-sectional stakeholders. These findings support evidence from previous studies $[4,26,47,62]$ and contribute to the description of gaps in the system of institutional support for CE. The lack of interest of Russian companies in such popular methods of increasing resource efficiency as the transition to renewable energy sources is explained by the lack of legislative incentives, which is typical for many developing countries. These results match those observed and explained in earlier studies, for example in [73].

\subsection{Clustering}

Further, the data collected on Russian enterprises was supplemented with the Flash Eurobarometer 456 study data for each European country separately. Clustering was carried out by the k-means method in several stages. At the first stage, clustering was carried out in all variables representing the answers to questions Q1-Q8 (each answer option was considered as a separate variable, except for the "I don't know" option). The number of clusters was initially set equal to five, based on considerations of practical interpretation of the clustering results. As a result of the first stage, the following five clusters of countries were identified (Table 2).

Table 2. Clustering results based on the answers to all questions.

\begin{tabular}{ccccc}
\hline $\begin{array}{c}\text { Cluster 1 } \\
\text { (7 Countries) }\end{array}$ & $\begin{array}{c}\text { Cluster 2 } \\
\text { (6 Countries) }\end{array}$ & $\begin{array}{c}\text { Cluster 3 } \\
\text { (12 Countries) }\end{array}$ & $\begin{array}{c}\text { Cluster 4 } \\
\text { (8 Countries) }\end{array}$ & $\begin{array}{c}\text { Cluster 5 } \\
\text { (5 Countries) }\end{array}$ \\
\hline $\begin{array}{c}\text { El, HR, LV, HU, PL, SK, } \\
\text { RU }\end{array}$ & IE, ES, FR, UK, TR, US & $\begin{array}{c}\text { BE, CZ, DK, DE, IT, LU, } \\
\text { NL, AT, PT, FI, SE, IS }\end{array}$ & $\begin{array}{c}\text { BG, EE, LT, RO, MK, } \\
\text { AL, NO, MD }\end{array}$ & CY, MT, SI, ME, RS \\
\hline
\end{tabular}

Source: authoring.

We can note that not all variables have a statistically significant contribution to clustering (the differences between intragroup and intergroup variances are not statistically significant). Section Q2 (about additional resource efficiency actions that the company is planning to implement) has the answer "other". Section Q4 (about the amount of investments into resource-efficiency) does not contribute to the clustering answers "Nothing", "1-5\%", "6-10\%", "11-30\%", and "More than 30\%"). In section Q6 (about types of external support) the answers "private funding from a bank, investment company or venture capital funds" and "private funding from friends and relatives" do not contribute to the clustering. In section Q7 (about barriers) the answer "None" does not contribute, and in section Q8 (desirable kinds of help in implementation of resource-efficiency measures) the answers "Consultancy on how to improve resource efficiency in your company", "Clearer rules on the use of secondary raw materials", "Other", and "None" do not contribute to clustering.

As one can see from Table 2, Russia belongs to the same cluster with Israel, Croatia, Latvia, Hungary, Poland and Slovakia. The profiles of the countries in this cluster by distribution of all responses are shown in Figure 9. 


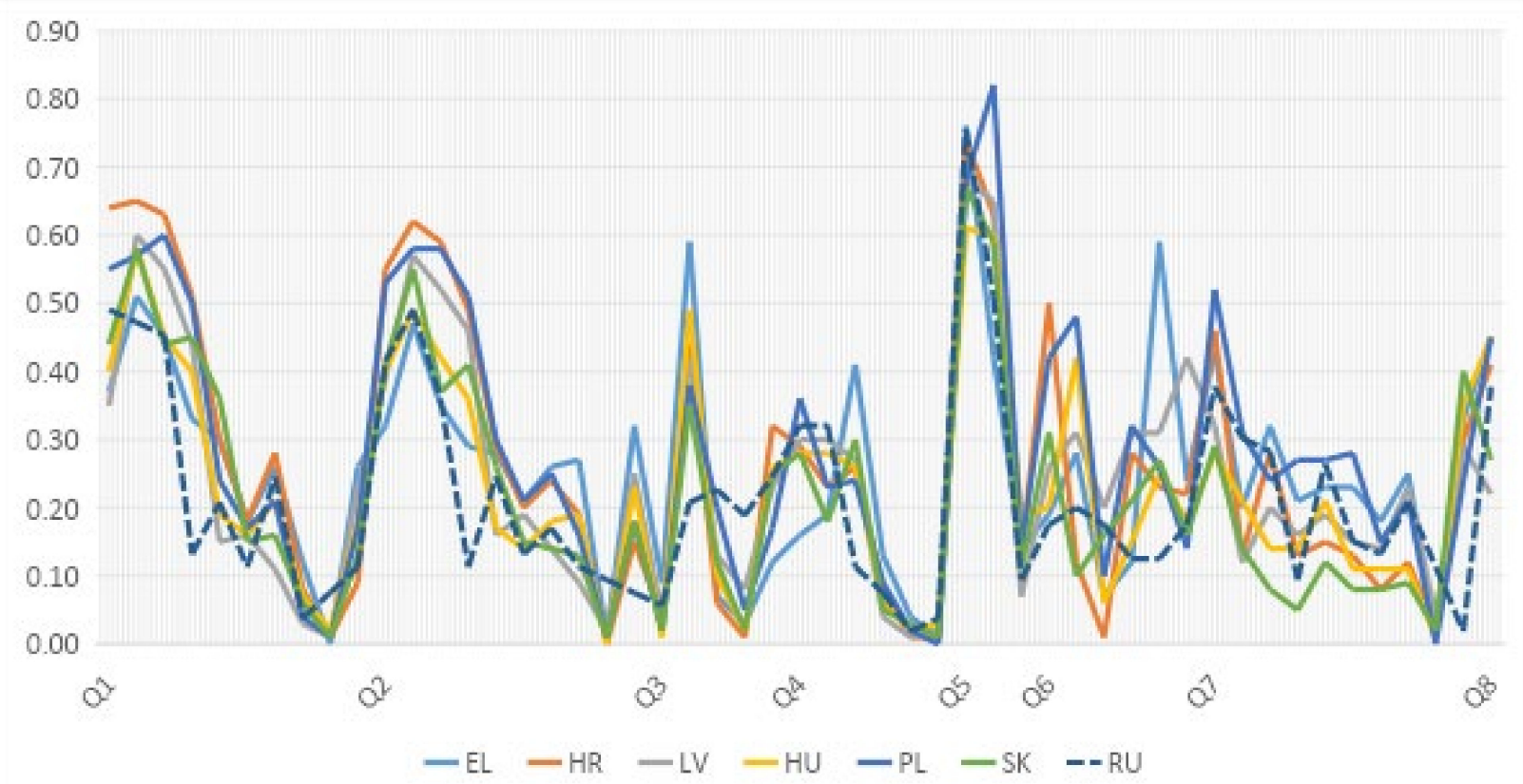

Figure 9. Profiles of the countries in Cluster 1 by distribution of all responses. Source: authors.

More detailed analysis was completed at the second stage; the division into clusters was carried out separately for each question. The clustering results are presented in Table 3.

Table 3. Clustering results based on the answers to each question separately.

\begin{tabular}{|c|c|c|c|c|}
\hline Question & $\begin{array}{l}\text { Not Significant } \\
\quad(p>0.05)\end{array}$ & Cluster & Number & Countries \\
\hline \multirow{5}{*}{$\begin{array}{l}\text { Q1. What actions is your } \\
\text { company undertaking to be } \\
\text { more resource efficient? }\end{array}$} & \multirow{5}{*}{ No } & 1 & 8 & $\begin{array}{l}\text { DK, EL, LV, HU, PL, SI, } \\
\text { SK, FI }\end{array}$ \\
\hline & & 2 & 11 & $\begin{array}{l}\text { BE, CZ, DE, HR, IT, LU, } \\
\text { MT, NL, AT, SE, IS }\end{array}$ \\
\hline & & 3 & 5 & $\mathrm{CY}, \mathrm{ME}, \mathrm{RS}, \mathrm{NO}, \mathrm{RU}$ \\
\hline & & 4 & 7 & $\begin{array}{l}\text { IE, ES, FR, PT, UK, TR, } \\
\text { US }\end{array}$ \\
\hline & & 5 & 7 & $\begin{array}{l}\text { BG, EE, LT, RO, MK, AL, } \\
\text { MD }\end{array}$ \\
\hline \multirow{5}{*}{$\begin{array}{l}\text { Q2. What are the additional } \\
\text { resource efficiency actions is } \\
\text { your company planning to } \\
\text { implement? }\end{array}$} & \multirow{5}{*}{$\begin{array}{l}\text { Q2.9 } \\
\text { (Other) }\end{array}$} & 1 & 10 & $\begin{array}{l}\mathrm{BE}, \mathrm{CZ}, \mathrm{DE}, \mathrm{HR}, \mathrm{IT}, \mathrm{NL}, \\
\mathrm{AT}, \mathrm{PL}, \mathrm{SE}, \mathrm{IS}\end{array}$ \\
\hline & & 2 & 6 & IE, ES, FR, UK, TR, US \\
\hline & & 3 & 9 & $\begin{array}{l}\text { EL, LV, LT, LU, HU, RO, } \\
\text { SK, FI, RU }\end{array}$ \\
\hline & & 4 & 8 & $\begin{array}{l}\mathrm{BG}, \mathrm{DK}, \mathrm{PT}, \mathrm{MK}, \mathrm{ME}, \mathrm{AL}, \\
\mathrm{NO}, \mathrm{MD}\end{array}$ \\
\hline & & 5 & 5 & EE, CY, MT, SI, RS \\
\hline
\end{tabular}


Table 3. Cont

\begin{tabular}{|c|c|c|c|c|}
\hline Question & $\begin{array}{l}\text { Not Significant } \\
\quad(p>0.05)\end{array}$ & Cluster & Number & Countries \\
\hline \multirow{5}{*}{$\begin{array}{l}\text { Q3. The impact of resource } \\
\text { efficiency actions on production } \\
\text { costs }\end{array}$} & \multirow{5}{*}{$\begin{array}{c}\text { Q3.1 } \\
\text { (significantly decreased) }\end{array}$} & 1 & 14 & $\begin{array}{l}\text { CZ, ES. HR, IT, LV, LT, } \\
\text { HU, AT, RO, SI, FI, RS, } \\
\text { AL, NO }\end{array}$ \\
\hline & & 2 & 8 & $\begin{array}{l}\text { BE, DE, EE, FR, CY, PT, } \\
\text { SK, SE }\end{array}$ \\
\hline & & 3 & 7 & $\begin{array}{l}\text { IE, MT, PL, TR, MD, US, } \\
\text { RU }\end{array}$ \\
\hline & & 4 & 5 & DK, LU, NL, UK, IS \\
\hline & & 5 & 4 & $\mathrm{BG}, \mathrm{EL}, \mathrm{MK}, \mathrm{ME}$ \\
\hline \multirow{5}{*}{$\begin{array}{l}\text { Q4. Investment in resource } \\
\text { efficiency actions }\end{array}$} & \multirow{5}{*}{$\begin{array}{c}\text { Q4.4 } \\
(6-10 \%) \\
\text { Q4.5 } \\
(11-30 \%) \\
\text { Q4.6 } \\
\text { (more than } 30 \% \text { ) }\end{array}$} & 1 & 2 & MK, AL \\
\hline & & 2 & 19 & $\begin{array}{l}\text { BE, BG, DK, EE, IE, HR, } \\
\text { IT, CY, LY, LU, HU, MT, } \\
\text { NL, PT, RO, SI, SK, FI, } \\
\text { UK }\end{array}$ \\
\hline & & 3 & 6 & DE, EL, ES, AT, ME, US \\
\hline & & 4 & 5 & FR, PL, SE, TR, RS \\
\hline & & 5 & 6 & $\mathrm{CZ}, \mathrm{LT}, \mathrm{IS}, \mathrm{NO}, \mathrm{MD}, \mathrm{RU}$ \\
\hline \multirow{5}{*}{$\begin{array}{l}\text { Q5. Types of support in resource } \\
\text { efficiency actions }\end{array}$} & \multirow{5}{*}{ No } & 1 & 8 & $\begin{array}{l}\text { BG, CZ, HR, LV, HU, PL, } \\
\text { SI, SK }\end{array}$ \\
\hline & & 2 & 4 & $\mathrm{RO}, \mathrm{MK}, \mathrm{AL}, \mathrm{MD}$ \\
\hline & & 3 & 10 & $\begin{array}{l}\text { BE, EE, EL, CY, LT, PT, } \\
\text { TR, ME, RS, RU }\end{array}$ \\
\hline & & 4 & 6 & DE, FR, MT, AT, FI, US \\
\hline & & 5 & 10 & $\begin{array}{l}\text { DK, IE, ES, IT, LU, NL, } \\
\text { SE, UK, IS, NO }\end{array}$ \\
\hline \multirow{5}{*}{$\begin{array}{l}\text { Q6. Types of external support } \\
\text { used by enterprises to be more } \\
\text { resource efficient }\end{array}$} & \multirow{5}{*}{$\begin{array}{l}\text { Q6.3 } \\
\text { (private funding from } \\
\text { friends and relatives) }\end{array}$} & 1 & 6 & CZ, DK, EL, ES, IT, IS \\
\hline & & 2 & 14 & $\begin{array}{l}\text { BE, DE, IE, FR, CY, LV, LT, } \\
\text { NL, AT, FI, SE, UK, TR, } \\
\text { US }\end{array}$ \\
\hline & & 3 & 4 & EE, RO, MK, MD \\
\hline & & 4 & 8 & $\begin{array}{l}\text { BG, HU, MT, PL, PT, ME, } \\
\text { RS, AL }\end{array}$ \\
\hline & & 5 & 6 & HR, LU, SI, SK, NO, RU \\
\hline \multirow{5}{*}{$\begin{array}{l}\text { Q7. Barriers encountered when } \\
\text { becoming more resource efficient }\end{array}$} & \multirow{5}{*}{ No } & 1 & 10 & $\begin{array}{l}\text { BG, CZ, EL, HR, LV, RO, } \\
\text { MK, IS, MD, RU }\end{array}$ \\
\hline & & 2 & 15 & $\begin{array}{l}\text { BE, DK, DE, IE, LU, HU, } \\
\text { NL, AT, PT, SI, FI, SE, ME, } \\
\text { NO, US }\end{array}$ \\
\hline & & 3 & 1 & $\mathrm{AL}$ \\
\hline & & 4 & 8 & $\begin{array}{l}\text { EE, IT, CY, LT, MT, SK, } \\
\text { UK, RS }\end{array}$ \\
\hline & & 5 & 4 & ES, FR, PL, TR \\
\hline
\end{tabular}


Table 3. Cont

\begin{tabular}{|c|c|c|c|c|}
\hline Question & $\begin{array}{l}\text { Not Significant } \\
\quad(p>0.05)\end{array}$ & Cluster & Number & Countries \\
\hline \multirow{5}{*}{$\begin{array}{l}\text { Q8. Desirable measures } \\
\text { supporting resource efficiency }\end{array}$} & \multirow{5}{*}{$\begin{array}{c}\text { Q8.9 } \\
\text { (Other) }\end{array}$} & 1 & 9 & $\begin{array}{l}\text { EE, IT, LV, LT, RO, SK, RS, } \\
\mathrm{Al}, \mathrm{NO}\end{array}$ \\
\hline & & 2 & 8 & $\begin{array}{l}\text { CZ, EL, ES, FR, HR, PL, } \\
\text { SI, RU }\end{array}$ \\
\hline & & 3 & 5 & LU, PT, FI, IS, US \\
\hline & & 4 & 8 & $\begin{array}{l}\text { BG, CY, HU, MT, UK, } \\
\text { MK, ME, MD }\end{array}$ \\
\hline & & 5 & 8 & $\begin{array}{l}\text { BE, DK, DE, IE, NL, AT, } \\
\text { SE, TR }\end{array}$ \\
\hline
\end{tabular}

Source: authors.

According to the current resource efficiency initiatives (Q1), Russia falls into one cluster with Cyprus, Montenegro, Serbia, and Norway. Companies in all countries of this cluster are characterized by a more passive use of almost all of the resource efficiency measures listed in the questionnaire, except for measures to sell scrap materials to other companies (Figure 10). According to the plans for the development of initiatives in resource efficiency (Q2), Russia is included in one cluster with such European countries as Greece, Latvia, Lithuania, Luxembourg, Hungary, Romania, Slovakia, and Finland. In general, these countries are characterized by the fact that the number of companies planning any measures to improve resource efficiency is lower than the European average for all options, without exception (Figure 10).

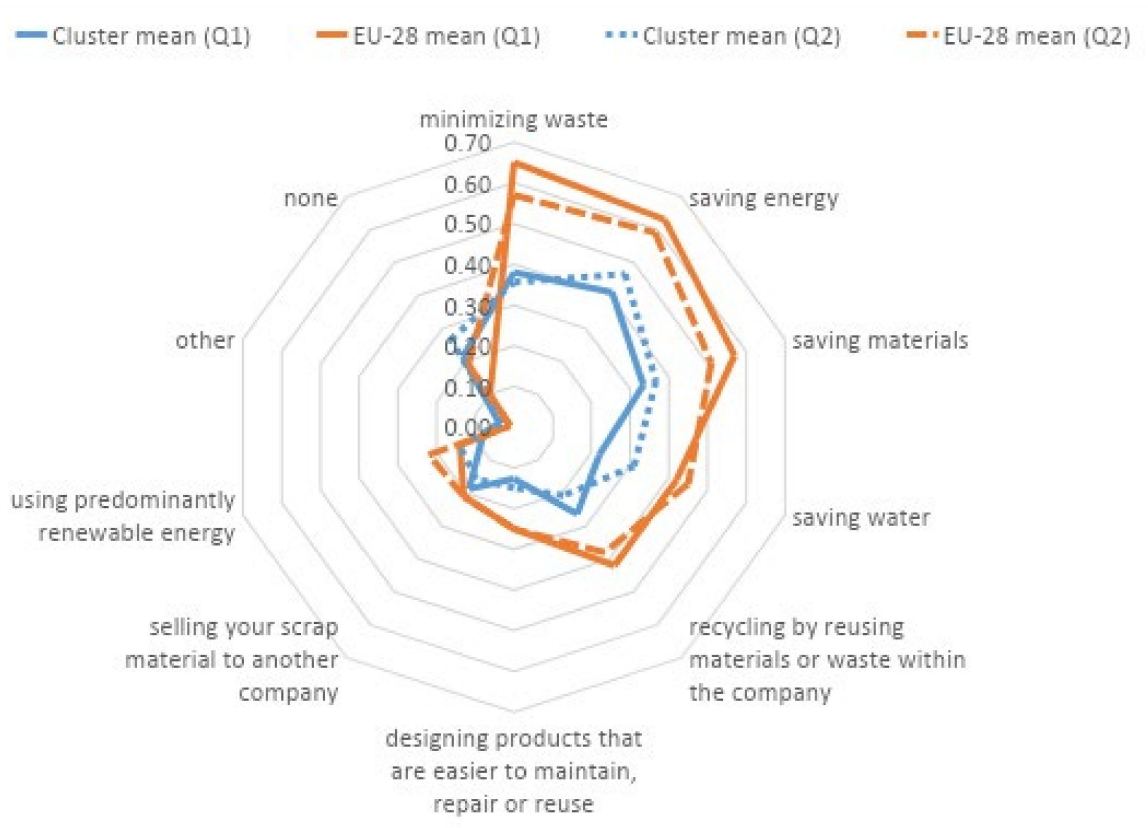

Figure 10. Comparing EU and clusters' means on Questions 1 and 2. Source: authors.

Regarding the impact of measures to improve resource efficiency on production costs (Q3), Russia is included in one cluster with Ireland, Malta, Poland, Turkey, Moldova, and the US. In this cluster, fewer companies than the EU average noted that the price was slightly decreased and not changed. Still, more companies than the EU average noted that the price was slightly increased and significantly increased. That is, the economic 
conditions in these countries do not contribute to immediate returns on projects to increase resource efficiency. When the prices of the resources to be saved (energy, water, raw materials) are low, it takes a long time for the additional resources saved from investments in technology and organizational innovations to improve resource efficiency to be realized. Regarding investments in improving resource efficiency (Q4), Russia is in the same group as the Czech Republic, Lithuania, Iceland, Norway, and Moldova. Companies in these countries are above the EU average in choosing the answer options "Nothing" and "Less than $1 \%$ " and less often the options " $1-5 \%$ " and " $6-10 \%$ ".

In terms of the types of support received in resource-efficiency measures (Q5), Russia is in the same group as Belgium, Estonia, Greece, Cyprus, Lithuania, Portugal, Turkey, Montenegro, and Serbia. Companies in these countries are more likely to rely on their financial resources than the EU-28 average, and less often on their technical competencies and external sources. According to the most common sources of external support (Q6), Russia is closest to Hungary, Luxembourg, Slovenia, Slovakia, and Norway. Companies in these countries are more than half as likely to turn to "advice or other non-financial assistance from private consulting and audit companies", almost half as often to use "private funding from a bank, investment company or venture capital fund" and about one and a half times less likely to use "advice or other non-financial assistance from business associations" than the EU average.

According to the identified barriers to improving energy efficiency (Q7), Russia is in one cluster with Bulgaria, the Czech Republic, Greece, Croatia, Latvia, Romania, the Former Yugoslav Republic of Macedonia, Iceland, and Moldova. Companies in these countries are much less likely to indicate the reason "Difficulty in choosing the right resource efficiency actions for your company" than the average in other EU countries, and also less likely to indicate as barriers "Difficulty to adapt environmental legislation to your company", "Cost of environmental actions", or "Lack of specific environmental expertise". In addition, companies from the countries in this cluster are much less likely to indicate that they are not hindered by any barriers (25\% versus $49 \%$ on average for the EU-28). Regarding the desired support measures (Q8), Russia is close to the Czech Republic, Greece, Spain, France, Croatia, Poland, and Slovenia. Companies from these countries indicate more often than the EU-28 average all of the first five options as desired support measures, with the greatest differences in frequency being noticeable in the first option, "Grants or subsidies".

\section{Conclusions and Policy Applications}

The purpose of the current study was to determine the barriers to and drivers of the practical implementation of circular economy principles in Russia, as a country that has not yet formed a system of institutional support for CE. The study made it possible to draw the following conclusions: as expected, the lack of a system of institutional support for the development of a circular economy, particularly resource efficiency, makes the problem of increasing resource efficiency for Russian companies less significant than for European ones. The only thing that Russian companies do as often as European ones is the sale of scrap metal. The least popular ways to improve resource efficiency among Russian companies are water saving and switching to renewable energy sources. Measures to improve resource efficiency are not as economically beneficial for Russian enterprises as European ones. In more than $40 \%$ of cases, the implementation of projects to improve resource efficiency leads to increased production costs due to low prices for resources and low demand for resource-efficient goods and services. It is most likely why Russian companies invest a much smaller share of their revenues in improving resource efficiency than companies in the EU. In order to improve this situation, changes in environmental legislation are needed, which would increase the importance of resource efficiency and make it economically profitable.

On average, Russian companies rely on external support to implement measures to improve resource efficiency two times less often than European ones. Moreover, this support type is quite specific, since it is not included in the list of suggested answer 
options but is rather the so-called "administrative resource", i.e., the ability to lobby on behalf of their interests through the local and regional authorities and sectoral government departments. In addition, Russian companies are about twice as likely as European ones to use debt financing from friends and relatives. All other types of institutional support are used less frequently, with the most significant gap in the frequency of using advice and nonfinancial assistance from government agencies, business associations and private consulting companies. The absence or underdevelopment of such institutions is a significant gap that splices a circular economy 2.0 .

As their main barriers to increasing resource efficiency Russian companies point to the complexity of administrative and regulatory procedures, the lack of practical application of regulatory documents to specific situations, outdated rules or technical regulations, and the high cost of projects to improve resource efficiency. Therefore, changing the regulatory framework to promote circular economy 2.0 is a priority task for the development of the system of institutional support, and can be completed only at the state level.

As the most interesting result of the study, we can highlight the answers of Russian companies about the changes in the circular economy 2.0 support system which are preferable for them. These are not even grants and subsidies (which are as desirable for Russian companies as for European ones), but demonstration projects, more active cooperation with companies in other sectors for the sale of byproducts and reuse of materials, and consulting support and databases with information on projects to improve resource efficiency. It is worthwhile to note that all of these desirable forms of support can be created by international business even in the absence of the involvement of government institutions.

Therefore, the most significant difference between countries with a mature system of institutional support and Russia lies in the regulatory sphere, and information and awareness about new available technologies and ways to increase resource efficiency, commercial attractiveness, and organizational feasibility. Changes in the first sphere are impossible without the participation of the national authorities, while changes in the information sphere are feasible even without the government's support. The initiators of such changes can be international companies with access to new resource-efficient technologies and organizing business processes.

The present study has several theoretical and practical implications. First, it contributes to the knowledge of CE barriers and drivers in the developing countries. It analyses the Russian company's state of the art in the CE field and strengthens the concept of CE by studying its connection with resource efficiency. It also provides a further understanding of resource-efficiency policies as possible enabling factors for the implementation of circular economy principles in the countries with a lack of institutions for CE support. Policy makers and managers dealing with CE models in countries with immature institutional support systems should focus on collaborative initiatives with multinational companies with developed CE models and appeal to their knowledge and databases.

As for the limitations of the study, the following should be noted. The comparability of the data obtained in the survey with the data of European companies is ensured by a unified methodology. However, the latest data for European companies was collected in 2017 and published in 2018. After that, studies using the Flash Eurobarometer methodology were no longer carried out. However, this does not diminish the validity and value of the results obtained since the development of the circular economy in Russia is lagging compared to European countries. The time difference between the collection of European and Russian data is three years. This time lag makes it possible to study the changes in the institutional system that neighboring countries have undertaken in clusters from 2017 to the present. It also makes it possible to assess the effectiveness of such changes and their potential applicability for Russia.

Another limitation is the small sample of Russian companies. This limitation is difficult to overcome due to the closed nature of Russian companies, especially small and medium-sized enterprises, which are not required by law to disclose information about themselves. As a positive aspect, to some extent counterbalancing this limitation, it can be 
noted that there were no unsuitable companies in the sample of Russian enterprises, for example, micro-enterprises with one employee and having neither production nor office space, etc.

The most obvious prospects for future research lie in the comparative analysis of strategies and roadmaps for CE development in countries that belong to the same clusters as Russia. Studying the specific experience of developing the institutional support system in these countries and assessing its effectiveness will make it possible to develop more substantiated policy recommendations for Russia and other countries with similar institutional systems.

Another direction of future research might be the detailed study of the multivariate relationship between the technical, economic and institutional factors affecting circularity among Russian companies. The present findings give direction to a potentially more sophisticated study that can include multiple factors of incentives and barriers to circularity and may disclose more specific areas for policy intervention.

Author Contributions: Conceptualization and methodology, S.R. (Svetlana Ratner); software, S.R. (Svetlana Ratner); validation, S.R. (Svetlana Ratner), K.G. and S.R. (Svetlana Revinova); formal analysis, I.L.; investigation, S.R. (Svetlana Ratner); resources, K.G.; data curation, S.R. (Svetlana Revinova); writing_original draft preparation, S.R. (Svetlana Ratner); writing—review and editing, K.G.; visualization, K.G.; supervision, S.R. (Svetlana Ratner); project administration, S.R. (Svetlana Ratner); funding acquisition, I.L. All authors have read and agreed to the published version of the manuscript.

Funding: This paper has been supported by the RUDN University Strategic Academic Leadership Program.

Institutional Review Board Statement: Not applicable.

Informed Consent Statement: Not applicable.

Data Availability Statement: https://pfur-my.sharepoint.com/:x:/g/personal/gomonov_kg_pfur_ ru/EeKF7b0cD8FAgSQkSvXTG84BVmfgt_pR8MYcP1YXzA6eNg?e=NTbt4m (accessed on 25 July 2021).

Acknowledgments: The authors thank all survey participants.

Conflicts of Interest: The authors declare no conflict of interest.

\section{Abbreviations}

$\begin{array}{ll}\text { CE } & \text { Circular Economy } \\ \text { AL } & \text { Albania } \\ \text { AT } & \text { Austria } \\ \text { BE } & \text { Belgium } \\ \text { BG } & \text { Bulgaria } \\ \text { CY } & \text { Cyprus } \\ \text { CZ } & \text { Czech Republic } \\ \text { DE } & \text { Germany } \\ \text { DK } & \text { Denmark } \\ \text { EE } & \text { Estonia } \\ \text { EL } & \text { Greece } \\ \text { ES } & \text { Spain } \\ \text { FI } & \text { Finland } \\ \text { FR } & \text { France } \\ \text { HR } & \text { Croatia } \\ \text { HU } & \text { Hungary } \\ \text { IE } & \text { Ireland } \\ \text { IS } & \text { Iceland }\end{array}$




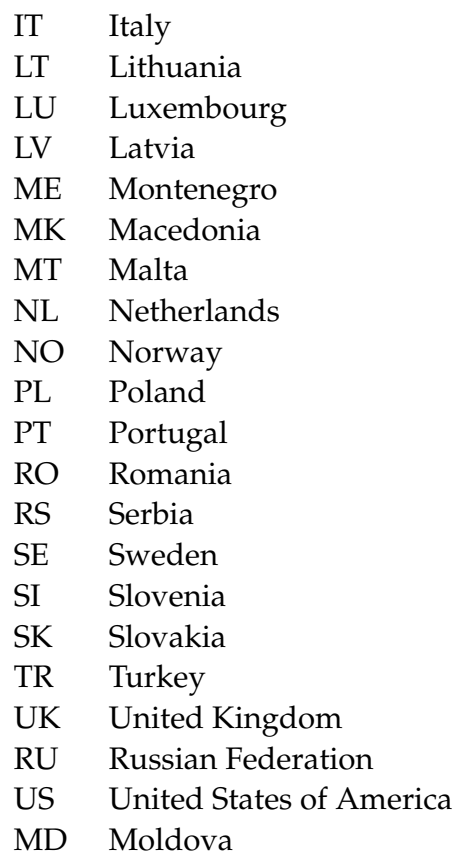

\section{Appendix A}

Questionnaire

\begin{tabular}{|c|c|}
\hline Question & Answer Options with Codes \\
\hline $\begin{array}{l}\text { Q1. What actions is your company undertaking to be more } \\
\text { resource efficient? (MULTIPLE ANSWERS POSSIBLE) }\end{array}$ & $\begin{array}{l}\text { Saving water } 1 \\
\text { Saving energy } 2 \\
\text { Using predominantly renewable energy (e.g., including own } \\
\text { production through solar panels, etc.) } 3 \\
\text { Saving materials } 4 \\
\text { Minimising waste } 5 \\
\text { Selling your scrap material to another company } 6 \\
\text { Recycling, by reusing material or waste within the company } 7 \\
\text { Designing products that are easier to maintain, repair or reuse } 8 \\
\text { Other } 9 \\
\text { None } 10 \\
\text { DK/NA } 11\end{array}$ \\
\hline $\begin{array}{l}\text { Q2. Over the next two years, what are the additional resource } \\
\text { efficiency actions that your company is planning to implement? } \\
\text { (MULTIPLE ANSWERS POSSIBLE) }\end{array}$ & $\begin{array}{l}\text { Save water 1, } \\
\text { Save energy 2, } \\
\text { Use predominantly renewable energy (e.g., including own } \\
\text { production through solar panels, etc.) 3, } \\
\text { Save materials } 4, \\
\text { Minimise waste } 5 \text {, } \\
\text { Sell your scrap material to another company 6, } \\
\text { Recycle, by reusing material or waste within the company } 7 \text {, } \\
\text { Design products that are easier to maintain, repair or reuse } 8 \text {, } \\
\text { Other } 9 \text {, } \\
\text { None } 10 \\
\text { DK/NA } 11\end{array}$ \\
\hline
\end{tabular}


Q3. What impact have the undertaken resource efficiency actions had on the production costs over the past two years? The production costs have... (ONE ANSWER ONLY)
Significantly decreased 1

Slightly decreased 2

Slightly increased 3

Significantly increased 4

Not changed 5

DK/NA 6

Nothing 1

Less than $1 \%$ of annual turnover 2

$1 \%-5 \%$ of annual turnover 3

$6 \%-10 \%$ of annual turnover 4

Q4. Over the past two years, how much have you invested on $11 \%$ - $30 \%$ of annual turnover 5 ONLY)

More than $30 \%$ of annual turnover 6

DK/NA 7

Its own financial resources 1 ,

Q5. Which type of support does your company rely on in its efforts to be more resourceefficient? (MULTIPLE ANSWERS POSSIBLE)

Its own technical expertise 2,

External support 3,

Other 4,

\section{DK/NA 5}

Public funding such as grants, guarantees or loans 1,

Private funding from a bank, investment company or venture capital fund 2,

Private funding from friends and relatives 3 ,

Advice or other non-financial assistance from public administration 4,

Q6. More precisely, which type of external support is it? (MULTIPLE ANSWERS POSSIBLE)

Advice or other non-financial assistance from private consulting and auditcompanies 5,

Advice or other non-financial assistance from business associations 6 ,

Other 7,

DK/NA 8

Complexity of administrative or legal procedures 1 ,

Difficulty to adapt environmental legislation to your company 2 , Technical requirements of the legislation not being up to date 3 , Difficulty in choosing the right resource efficiency actions for your company 4 ,

Cost of environmental actions 5,

Q7. Did your company encounter any of the following Lack of specific environmental expertise 6, difficulties when trying to set up resource efficiency actions? (MULTIPLE ANSWERS POSSIBLE)

Lack of supply of required materials, parts, products or services 7,

Lack of demand for resource efficient products or services 8 ,

Other 9,

None 10

DK/NA 11 
A tool to self-assess how resource efficient your company is with respect to other companies 1 ,

Consultancy on how to improve resource efficiency in your company 2,

Grants or subsidies 3,

Advice on funding possibilities and financial planning for resource efficiency investments 4 ,

Demonstration of new technologies or processes to improve resource efficiency 5 ,

Q8. Which of the following would help your company the most to be more resource efficient? (MAX. 3 ANSWERS)
Database with case studies that show the benefits of resource efficiency for companies 6,

Better cooperation between companies across sectors so that new processes to re-use waste and by-products can be developed 7,

Abolition of legislative obstacles to the use of waste and by-products 8 ,

Other 9,

None 10

DK/NA 11

\section{References}

1. Lewandowski, M. Designing the business models for circular economy-Towards the conceptual framework. Sustainability 2016, 8, 43. [CrossRef]

2. Korhonen, J.; Honkasalo, A.; Seppälä, J. Circular economy: The concept and its limitations. Ecol. Econ. 2018, 143, 37-46. [CrossRef]

3. Nußholz, J. Circular Business models: Defining a concept and framing an emerging research field. Sustainability 2017, 9, 1810. [CrossRef]

4. Maitre-Ekern, E. Re-thinking producer responsibility for a sustainable circular economy from extended producer responsibility to pre-market producer responsibility. J. Clean. Prod. 2021, 286, 125454. [CrossRef]

5. Pazoki, M.; Zaccour, G. Dynamic strategic interactions between a municipality and a firm in the presence of an extended producer responsibility regulation. J. Clean. Prod. 2021, 292, 125966. [CrossRef]

6. Bocken, N.; Short, S. Towards a sufficiency-driven business model: Experiences and opportunities. Environ. Innov. Soc. Transit. 2016, 18, 41-61. [CrossRef]

7. Lahti, T.; Wincent, J.; Parida, V. A definition and theoretical review of the circular economy, value creation, and sustainable business models: Where are we now and where should research move in the future? Sustainability 2018, 10, 2799. [CrossRef]

8. De Jesus, A.; Mendonça, S. Lost in transition? Drivers and barriers in the eco-innovation road to the circular economy. Ecol. Econ. 2018, 145, 75-89. [CrossRef]

9. Domenech, T.; Bahn-Walkowiak, B. Transition towards a resource efficient circular economy in Europe: Policy lessons from the EU and the Member States. Ecol. Econ. 2019, 155, 7-19. [CrossRef]

10. Termeer, C.; Metze, T. More than peanuts: Transformation towards a circular economy through a small-wins governance framework. J. Clean. Prod. 2019, 240, 118272. [CrossRef]

11. Nikolaou, I.E.; Tsagarakis, K.P. An introduction to circular economy and sustainability: Some existing lessons and future directions. Sustain. Prod. Consum. 2021, 28, 600-609. [CrossRef]

12. Franco, M. Circular economy at the micro level: A dynamic view of incumbents' struggles and challenges in the textile industry. J. Clean. Prod. 2017, 168, 833-845. [CrossRef]

13. Llach, J.; Alonso-Almeida, M.D.M.; García-Castellví, A.; Bagur-Femenias, L. A fresh approach to context influence, development and performance in environmental management. Bus. Strat. Environ. 2014, 24, 855-872. [CrossRef]

14. Robaina, M.; Villar, J.; Pereira, E.T. The determinants for a circular economy in Europe. Environ. Sci. Pollut. Res. 2020, 27, 12566-12578. [CrossRef]

15. Closing the Loop_An EU Action Plan for the Circular Economy. 2021. Available online: https://eur-lex.europa.eu/resource. html?uri=cellar:8a8ef5e8-99a0-11e5-b3b7-01aa75ed71a1.0012.02/DOC_1\&format=PDF (accessed on 25 July 2021).

16. Towards a Circular Economy-Waste Management in the EU-Think Tank. Europarl.europa.eu. 2021. Available online: http: //www.europarl.europa.eu/thinktank/en/document.html?reference=EPRS_STU(2017)581913 (accessed on 25 July 2021).

17. Repo, P.; Anttonen, M.; Mykkänen, J.; Lammi, M. Lack of congruence between European citizen perspectives and policies on circular economy. Eur. J. Sustain. Dev. 2018, 7, 249-264. [CrossRef]

18. Ranta, V.; Aarikka-Stenroos, L.; Ritala, P.; Mäkinen, S.J. Exploring institutional drivers and barriers of the circular economy: A cross-regional comparison of China, the US, and Europe. Resour. Conserv. Recycl. 2018, 135, 70-82. [CrossRef] 
19. Russell, M.; Gianoli, A.; Grafakos, S. Getting the ball rolling: An exploration of the drivers and barriers towards the implementation of bottom-up circular economy initiatives in Amsterdam and Rotterdam. J. Environ. Plan. Manag. 2019, 63, $1903-1926$. [CrossRef]

20. Levoso, A.S.; Gasol, C.M.; Martínez-Blanco, J.; Durany, X.G.; Lehmann, M.; Gaya, R.F. Methodological framework for the implementation of circular economy in urban systems. J. Clean. Prod. 2020, 248, 119227. [CrossRef]

21. Van den Bergh, J. Six policy perspectives on the future of a semi-circular economy. Resour. Conserv. Recycl. 2020, 160, 104898. [CrossRef]

22. Kirchherr, J.; Piscicelli, L.; Bour, R.; Kostense-Smit, E.; Muller, J.; Huibrechtse-Truijens, A.; Hekkert, M. Barriers to the circular economy: Evidence from the European Union (EU). Ecol. Econ. 2018, 150, 264-272. [CrossRef]

23. Brown, P.; Bocken, N.; Balkenende, R. Why do companies pursue collaborative circular oriented innovation? Sustainability 2019, 11, 635. [CrossRef]

24. Scheepens, A.E.; Vogtländer, J.G.; Brezet, J.C. Two life cycle assessment (LCA) based methods to analyse and design complex (regional) circular economy systems. Case: Making water tourism more sustainable. J. Clean. Prod. 2016, 114, 257-268. [CrossRef]

25. De Abreu, M.C.S.; Ceglia, D. On the implementation of a circular economy: The role of institutional capacity-building through industrial symbiosis. Resour. Conserv. Recycl. 2018, 138, 99-109. [CrossRef]

26. Sarja, M.; Onkila, T.; Mäkelä, M. A systematic literature review of the transition to the circular economy in business organizations: Obstacles, catalysts and ambivalences. J. Clean. Prod. 2021, 286, 125492. [CrossRef]

27. Cramer, J.M. Practice-based model for implementing circular economy: The case of the Amsterdam Metropolitan Area. J. Clean. Prod. 2020, 255, 120255. [CrossRef]

28. Wang, N.; Lee, J.C.K.; Zhang, J.; Chen, H.; Li, H. Evaluation of Urban circular economy development: An empirical research of 40 cities in China. J. Clean. Prod. 2018, 180, 876-887. [CrossRef]

29. Johansson, N.; Henriksson, M. Circular economy running in circles? A discourse analysis of shifts in ideas of circularity in Swedish environmental policy. Sustain. Prod. Consum. 2020, 23, 148-156. [CrossRef]

30. Momete, D.C. A unified framework for assessing the readiness of European Union economies to migrate to a circular modelling. Sci. Total Environ. 2020, 718, 137375. [CrossRef] [PubMed]

31. Prendeville, S.; Cherim, E.; Bocken, N. Circular cities: Mapping six cities in transition. Environ. Innov. Soc. Transit. 2018, 26, 171-194. [CrossRef]

32. Ghisellini, P.; Ulgiati, S. Circular economy transition in Italy. Achievements, perspectives and constraints. J. Clean. Prod. 2020, 243, 118360. [CrossRef]

33. Dagilienè, L.; Varaniūtė, V.; Bruneckienė, J. Local governments' perspective on implementing the circular economy: A framework for future solutions. J. Clean. Prod. 2021, 310, 127340. [CrossRef]

34. Mazur-Wierzbicka, E. Towards circular economy-A comparative analysis of the countries of the European Union. Resources 2021, 10, 49. [CrossRef]

35. Semenova, G. Global environmental problems in Russia. E3S Web Conf. 2020, 157, 02023. [CrossRef]

36. Vedysheva, N.; Mukhlynina, M.; Vinogradova, E.; Nikiforov, A.; Efimova, O. Sustainable management of municipal solid waste: A systematic approach and legal challenges. E3S Web Conf. 2020, 208, 06007. [CrossRef]

37. Ratner, S.; Ratner, P. Regional energy efficiency programs in Russia: The factors of success. Region 2016, 3, 69. [CrossRef]

38. Berezin, A.; Ratner, S. Policy transition to low-carbon economy in Russia: State support measures. In Proceedings of the 13th International Days of Statistics and Economics Conference, Prague, Czech Republic, 5-7 September 2019; pp. 5-7. [CrossRef]

39. Balashova, S.; Ratner, S.; Gomonov, K.; Berezin, A. Modeling consumer and industry reaction to renewable support schemes: Empirical evidence from the Usa and applications for Russia. Int. J. Energy Econ. Policy 2020, 10, 158-167. [CrossRef]

40. Albrecht, M.; Yarovoy, G.; Karginova-Gubinova, V. Russia's waste policy and rural waste management in the Karelian Republic: Building up a ruin to come? Fenn. Int. J. Geogr. 2020, 198, 135-150. [CrossRef]

41. Reike, D.; Vermeulen, W.J.V.; Witjes, S. The circular economy: New or refurbished as CE 3.0?-Exploring controversies in the conceptualization of the circular economy through a focus on history and resource value retention options. Resour. Conserv. Recycl. 2018, 135, 246-264. [CrossRef]

42. Schöggl, J.-P.; Stumpf, L.; Baumgartner, R.J. The narrative of sustainability and circular economy-A longitudinal review of two decades of research. Resour. Conserv. Recycl. 2020, 163, 105073. [CrossRef]

43. Stumpf, L.; Schöggl, J.-P.; Baumgartner, R.J. Climbing up the circularity ladder?-A mixed-methods analysis of circular economy in business practice. J. Clean. Prod. 2021, 316, 128158. [CrossRef]

44. Di Maio, F.; Rem, P.C.; Baldé, K.; Polder, M. Measuring resource efficiency and circular economy: A market value approach. Resour. Conserv. Recycl. 2017, 122, 163-171. [CrossRef]

45. Figge, F.; Thorpe, A.S.; Givry, P.; Canning, L.; Franklin-Johnson, E. Longevity and circularity as indicators of eco-efficient resource use in the circular economy. Ecol. Econ. 2018, 150, 297-306. [CrossRef]

46. Cainelli, G.; D'Amato, A.; Mazzanti, M. Resource efficient eco-innovations for a circular economy: Evidence from EU firms. Res. Policy 2020, 49, 103827. [CrossRef]

47. Holzer, D.; Rauter, R.; Fleiß, E.; Stern, T. Mind the gap: Towards a systematic circular economy encouragement of small and medium-sized companies. J. Clean. Prod. 2021, 298, 126696. [CrossRef] 
48. Ma, S.; Hu, S.; Chen, D.; Zhu, B. A case study of a phosphorus chemical firm's application of resource efficiency and eco-efficiency in industrial metabolism under circular economy. J. Clean. Prod. 2015, 87, 839-849. [CrossRef]

49. Ncube, A.; Matsika, R.; Mangori, L.; Ulgiati, S. Moving towards resource efficiency and circular economy in the brick manufacturing sector in Zimbabwe. J. Clean. Prod. 2021, 281, 125238. [CrossRef]

50. Wang, N.; Guo, J.; Zhang, X.; Zhang, J.; Li, Z.; Meng, F.; Zhang, B.; Ren, X. The circular economy transformation in industrial parks: Theoretical reframing of the resource and environment matrix. Resour. Conserv. Recycl. 2021, 167, 105251. [CrossRef]

51. Ferronato, N.; Rada, E.C.; Portillo, M.A.G.; Cioca, L.I.; Ragazzi, M.; Torretta, V. Introduction of the circular economy within developing regions: A comparative analysis of advantages and opportunities for waste valorization. J. Environ. Manag. 2019, 230, 366-378. [CrossRef]

52. Geissdoerfer, M.; Pieroni, M.P.; Pigosso, D.C.; Soufani, K. Circular business models: A review. J. Clean. Prod. 2020, $277,123741$. [CrossRef]

53. Van Loon, P.; Diener, D.; Harris, S. Circular products and business models and environmental impact reductions: Current knowledge and knowledge gaps. J. Clean. Prod. 2021, 288, 125627. [CrossRef]

54. Barros, M.V.; Salvador, R.; Prado, G.F.D.; De Francisco, A.C.; Piekarski, C.M. Circular economy as a driver to sustainable businesses. Clean. Environ. Syst. 2021, 2, 100006. [CrossRef]

55. Centobelli, P.; Cerchione, R.; Chiaroni, D.; Del Vecchio, P.; Urbinati, A. Designing business models in circular economy: A systematic literature review and research agenda. Bus. Strat. Environ. 2020, 29, 1734-1749. [CrossRef]

56. Werning, J.P.; Spinler, S. Transition to circular economy on firm level: Barrier identification and prioritization along the value chain. J. Clean. Prod. 2020, 245, 118609. [CrossRef]

57. Morseletto, P. Targets for a circular economy. Resour. Conserv. Recycl. 2020, 153, 104553. [CrossRef]

58. Urbinati, A.; Chiaroni, D.; Chiesa, V. Towards a new taxonomy of circular economy business models. J. Clean. Prod. 2017, 168, 487-498. [CrossRef]

59. Salvador, R.; Barros, M.V.; Freire, F.; Halog, A.; Piekarski, C.M.; De Francisco, A.C. Circular economy strategies on business modelling: Identifying the greatest influences. J. Clean. Prod. 2021, 299, 126918. [CrossRef]

60. Kristoffersen, E.; Mikalef, P.; Blomsma, F.; Li, J. The effects of business analytics capability on circular economy implementation, resource orchestration capability, and firm performance. Int. J. Prod. Econ. 2021, 239, 108205. [CrossRef]

61. Kristoffersen, E.; Blomsma, F.; Mikalef, P.; Li, J. The smart circular economy: A digital-enabled circular strategies framework for manufacturing companies. J. Bus. Res. 2020, 120, 241-261. [CrossRef]

62. Alonso-Almeida, M.D.M.; Rodriguez-Anton, J.M.; Bagur-Femenías, L.; Perramon, J. Institutional entrepreneurship enablers to promote circular economy in the European Union: Impacts on transition towards a more circular economy. J. Clean. Prod. 2021, 281, 124841. [CrossRef]

63. Fortunati, S.; Martiniello, L.; Morea, D. The Strategic role of the corporate social responsibility and circular economy in the cosmetic industry. Sustainability 2020, 12, 5120. [CrossRef]

64. Fortunati, S.; Morea, D.; Mosconi, E.M. Circular economy and corporate social responsibility in the agricultural system: Cases study of the Italian agri-food industry. Agric. Econ. 2020, 66, 489-498.

65. Flash Eurobarometer 456: SMEs, Resource Efficiency and Green Markets. Data.europa.eu. 2021. Available online: https: / / data.europa.eu/data/datasets/s2151_456_eng?locale=en (accessed on 25 July 2021).

66. Directorate-General for Communication “Media Monitoring and Analysis" Unit. 2021. Available online: http://ec.europa.eu/ commfrontoffice/publicopinion (accessed on 25 July 2021).

67. García-Sánchez, I.-M.; Somohano-Rodríguez, F.-M.; Amor-Esteban, V.; Frías-Aceituno, J.-V. Which region and which sector leads the circular economy? CEBIX, a multivariant index based on business actions. J. Environ. Manag. 2021, 297, 113299. [CrossRef]

68. D'Amato, D.; Korhonen, J. Integrating the green economy, circular economy and bioeconomy in a strategic sustainability framework. Ecol. Econ. 2021, 188, 107143. [CrossRef]

69. Ratner, S.; Iosifov, V. Eco-management and eco-standardization in Russia: The perspectives and barriers for development. J. Environ. Manag. Tour. 2017, 1, 247-258. [CrossRef]

70. Fura, B.; Stec, M.; Miś, T. Statistical evaluation of the level of development of circular economy in European Union member countries. Energies 2020, 13, 6401. [CrossRef]

71. Gomonov, K.; Ratner, S.; Lazanyuk, I.; Revinova, S. Clustering of EU countries by the level of circular economy: An object-oriented approach. Sustainability 2021, 13, 7158. [CrossRef]

72. Ward, J. Hierarchical grouping to optimize an objective function. J. Am. Stat. Assoc. 1963, 58, 236-244. [CrossRef]

73. Sadik-Zada, E.R.; Ferrari, M. Environmental policy stringency, technical progress and pollution haven hypothesis. Sustainability 2020, 12, 3880. [CrossRef] 